\title{
Metaconflict and international human rights law in dealing with Northern Ireland's past
}

\author{
Louise Mallinder* \\ Professor of Law, Queen's University Belfast, Northern Ireland, UK
}

In many post-conflict societies, political actors battle to ensure the dominancy of their preferred narratives regarding the causes of and responsibilities for past violence. They wage these conflicts about the conflict to instrumentalise narratives of the past to serve their contemporary political aims, but in doing so, they contribute to the endurance of societal divisions which can have destructive effects on the promotion of reconciliation and political stability. Metaconflicts can be particularly heated with respect to the design and implementation of measures to deliver victims' rights to truth, justice and reparations, as it is through these processes that competing and complex communal narratives of the past are exposed and challenged. This article interrogates how metaconflicts shape political actors' engagement with or resistance to international legal obligations to investigate and prosecute past violations. The approaches of Northern Ireland's Unionist political parties and Unionist-aligned organisations to the United Kingdom's obligations under the European Convention of Human Rights are used as a case study. Through theoretically informed qualitative analysis of publicly available submissions made by these groups to an official consultation and parliamentary inquiries taking place during 2018, this article identifies four strategies used by Unionists to resist approaches to dealing with the past that they view as contrary to their interests. On this basis, the article argues that these actors understand law as a means to construct and provide official recognition for communally resonant moral and social categories and norms, and that, as such, legal principles such as the equality of the law, nondiscrimination and independence within the criminal justice process are viewed as secondary to political concerns. It concludes that reducing the metaconflict's destructive effects requires all parties to recognise the need for political generosity and compromise and to develop more substantive engagement with the principles of universality and equality underpinning international human rights law.

Keywords: metaconflict, Northern Ireland, Unionists, duty to investigate, balance in decisions to prosecute, statutes of limitations

\section{INTRODUCTION}

Metaconflicts are inevitable. In all societies that undergo armed conflict or other deep social cleavages, these conflicts about the conflict are played out in disputes over the

* Email: 1.mallinder@qub.ac.uk. An earlier version of this article was presented as the CILJLCIL Annual Lecture 2019 at the Lauterpacht Centre for International Law, University of Cambridge, UK (25 January 2019). The author would like to thank the participants of that event for their feedback. The author would also like to thank Professor Kieran McEvoy, Dr Cheryl Lawther and Brian Gormally for their comments on earlier versions of this article. 
causes, nature and consequences of violence. ${ }^{1}$ While individuals can and do form their own understandings of the conflict, often metaconflicts are fought over the rival collective memories developed by distinct social groups to frame and transmit their understandings of the conflict. Such disputes can develop from, and in turn shape, the development of rival ideologies and visions of how society should be governed. ${ }^{2}$ In contexts where one social group is dominant in terms of access to power and the means of cultural production, their account of the conflict may be presented as a hegemonic narrative. ${ }^{3}$ In response, minority groups engage in metaconflict when they posit their own narratives as a counterpoint and challenge to hegemonic accounts. These strategies may include articulating historical narratives that are used to call upon elites to account for historical wrongs. ${ }^{4}$ Metaconflicts can be highly destructive. ${ }^{5}$ This destructivity arises where metaconflicts trap parties to the conflict in entrenched positions from which they struggle to 'seek accommodation and inclusion rather than hegemony and exclusion'. ${ }^{6}$ In this way, Horowitz, one of the first scholars to write about metaconflicts, described them as 'a constraint on the imagination and a constraint on innovation'?

Since this term 'metaconflict' was coined by political scientists analysing the prospects for a democratic transition in South Africa, ${ }^{8}$ scholars have applied it to diverse contexts including Sudan, ${ }^{9}$ Burundi, ${ }^{10}$ Bosnia-Herzegovina, ${ }^{11}$ Cyprus, ${ }^{12}$ Iraq, ${ }^{13}$ Israel and Palestine, ${ }^{14}$ and Northern Ireland. ${ }^{15}$ Existing literature has largely focused on how metaconflicts shape the nature of peacebuilding programmes, powersharing arrangements and the creation of new political institutions. Questions of human rights have generally arisen with respect to how individual rights are balanced with group rights within the new political structures. ${ }^{16}$ This article takes a different approach by

1. John McGarry and Brendan O'Leary, Explaining Northern Ireland: Broken Images (Blackwell, Oxford 1995) 1.

2. John McGarry, 'Conflicts and Metaconflicts: Northern Ireland and Lessons for Other Hard Cases', Lecture delivered at Dalhousie University, Canada (Trudeau Foundation 2013) 47.

3. Jeffrey K Olick, The Politics of Regret: On Collective Memory and Historical Responsibility (Routledge, New York/Abingdon 2007) 24.

4. Ibid 129.

5. Vassilis K Fouskas, 'Iraq and Meta-Conflict' in Vassilis K Fouskas (ed), The Politics of Conflict: A Survey (Routledge, London 2007) 166, 181.

6. Donald L Horowitz, A Democratic South Africa? Constitutional Engineering in a Divided Society (University of California Press, Berkeley 1991) 111.

7. Ibid 28; Fouskas (n 5) 181.

8. Horowitz (n 6) 28.

9. Sharath Srinivasan, 'Negotiating Violence: Sudan's Peacemakers and the War in Darfur' (2014) 113 African Affairs 24.

10. René Lemarchand, Burundi: Ethnic Conflict and Genocide (CUP, Cambridge 1994).

11. Goran Tepšić, 'Building Nations Instead of Peace(s): The Bosnian Metaconflict' (2017) 16 Serbian Political Thought 23.

12. Edel Hughes, Turkey's Accession to the European Union: The Politics of Exclusion? (Routledge, Abingdon/New York 2011).

13. Fouskas (n 5).

14. Ron Dudai, "Does Any of This Matter?" Transitional Justice and the Israel-Palestinian Conflict' in David Downes, Paul Rock, Christine Chinkin and Conor Gearty (eds), Crime, Social Control, and Human Rights: From Moral Panics to States of Denial, Essays in Honour of Stanley Cohen (Willan Publishing, Cullompton 2007) 339.

15. McGarry and O'Leary (n 1).

16. See eg McGarry (n 2) 77. 
exploring the significance of metaconflicts in the development and implementation of measures to address past human rights violations. International human rights law is intended to provide a transcendent set of obligations to which States must adhere. Most relevantly for dealing with the past, this includes obligations to investigate, prosecute, provide reparations, and prevent a repetition of violations. ${ }^{17}$ However, drawing on socio-legal perspectives, this article explores the ways in which attitudes towards international human rights obligations intersect with contested narratives of the past. Thus, this article uses Northern Ireland as a case study, to ask: how do metaconflicts in post-conflict societies shape political actors' engagement with, or resistance to, international legal obligations to investigate and prosecute past violations? ${ }^{18}$

Interrogating the metaconflict should be a key component of conflict transformation. ${ }^{19}$ For example, Mac Ginty and du Toit argue that where antagonistic parties seek to move beyond violent conflict, they should reach a 'metabargain' in which they come to some broad, shared understanding of the root causes of their dispute. This in turn should provide a framework "within which the specific constitutional mechanisms constituting the peace accord will be located' ${ }^{20}$ Others have contended that, without a metabargain, disputes over the past will endure and can inhibit the creation of a stable settlement as rival parties will continue to harbour incompatible visions of their political future. ${ }^{21}$ Although Northern Ireland recently celebrated the twentieth anniversary of its peace agreement, as is well known, the primary political actors have yet to reach consensus over the causes and consequences of and responsibilities for the violence perpetrated between 1968 and 1998. Much less is there an agreement over the vexed issue of Northern Ireland's constitutional status, ${ }^{22}$ as the Belfast or Good Friday Agreement sought only to establish democratic structures in which these difficult issues could be resolved peacefully. ${ }^{23}$ However, the fragility of these structures has been exposed by the collapse of the devolved, powersharing institutions in 2017 and the uncertainty created by the 2016 vote by the electorate in England and Wales that the United Kingdom should leave the European Union. In addition, the Agreement contained little provision relating to the past. There were no commitments to truth and justice, nor amnesty. Bell argues that this absence is a product of the ambiguities at the heart of the agreement, which were viewed as necessary for the parties to sign it. ${ }^{24}$ This necessity was due to the fact that

17. See eg Basic Principles and Guidelines on the Right to a Remedy and Reparation for Victims of Gross Violations of International Human Rights Law and Serious Violations of International Humanitarian Law, Adopted and proclaimed by General Assembly resolution 60/147 of 16 December 2005, principle 3.

18. The paper's focus on the pursuit of information and justice corresponds with the proposed institutions to deal with the past. During and since the conflict there have been a number of programmes to provide compensation and services to victims. In addition, multiple forms of institutional reform played a significant role in the Northern Ireland transition; however, they are excluded from this analysis as they were generally orientated towards ensuring greater protection and promotion of human rights in the post-Agreement context, than providing accountability for past wrongdoings.

19. McGarry (n 2) 74.

20. Roger Mac Ginty and Pierre du Toit, 'A Disparity of Esteem: Relative Group Status in Northern Ireland After the Belfast Agreement' (2007) 28 Political Psychology 13, 27.

21. Horowitz (n 6) 34.

22. Christine Bell, 'Dealing with the Past in Northern Ireland' (2002) 26 Fordham International Law Journal 1095, 1107.

23. Ibid 1099.

24. Ibid 1107. 
'there was simply no consensus as to what the conflict was about, nor upon whom the blame for it lay'. ${ }^{25}$

This absence of a metabargain over Northern Ireland's past has meant that the metaconflict continues to be waged. In this arena, the two main communities have developed distinct narratives to assert and contest the identification of the 'past' to be addressed or forgotten, the international legal framing to be applied to past crimes, ${ }^{26}$ and the delineations of individuals and institutions to be held responsible for past abuses. ${ }^{27}$ Political actors wage this metaconflict over the causes and responsibilities for past violations in order to 'tilt all transitional mechanisms' towards their preferred 'end point for transition', namely whether Northern Ireland remains within the United Kingdom or unites with Ireland. ${ }^{28}$ In recent years, these skirmishes have seemingly grown in intensity. This intensity is due in large part to the fact that since the 2014 Stormont House Agreement, Northern Ireland has been moving towards implementing its first comprehensive approach to dealing with the past and disputes over these proposals have provided fertile ground for metaconflict disputes. However, disputes over the past have also been a key source of tension in the fitful negotiations to restore Northern Ireland's devolved powersharing institutions. These legislative and political efforts are taking place against the backdrop of Brexit, which has raised renewed questions about the constitutional status of Northern Ireland, the impact of Brexit on commitments within the 1998 Agreement, and the continued existence of paramilitary groups within Northern Irish society. ${ }^{29}$ Within this context, the past is often characterised as a battlefield by political actors. For example, in a 2018 submission to a public consultation, the Ulster Unionist Party stated, 'This is the sad reality of Northern Ireland today, where the past has itself become a new theatre of conflict' ${ }^{30}$

To answer the research question, this article focuses on Unionist approaches to the past as Unionist political parties and institutions have historically been more cautious in embracing international human rights law than their Republican or Nationalist counterparts. Furthermore, in recent public submissions on legacy proposals, Unionists have articulated explicitly how their understanding of the 'metaconflict' shapes their perceptions of how international human rights law is and should be interpreted and applied to deal with the past. Through this focus on the law, this article differs from previous writings on Unionist attitudes to the past, which have considered, from sociological or political science standpoints, why Unionists have been opposed to the creation of a formal

25. Colm Campbell, Fionnuala Ní Aoláin and Colin Harvey, 'The Frontiers of Legal Analysis: Reframing the Transition in Northern Ireland' (2003) 66 Modern Law Review 317, 339.

26. Ibid.

27. Colm Campbell, 'The Spectre Returns: Conflicted Democracies, Truth Commissions and the

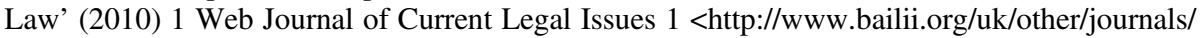
WebJCLI/2010/issue1/campbell1.html> accessed 14 March 2019; Christine Bell, 'Human Rights and Minority Protection' in John Darby and Roger Mac Ginty (eds), Contemporary Peacemaking: Conflict, Violence and Peace Processes (Palgrave Macmillan, Basingstoke 2003) $161,171$.

28. Christine Bell, 'Transitional Justice, Interdisciplinarity and the State of the "Field" or "Non-Field"' (2009) 3 International Journal of Transitional Justice 5, 25.

29. BrexitLawNI, 'BrexitLawNI Policy Report: Brexit and the Peace Process' (14 September 2018) <https://brexitlawni.org/library/resources/policy-report-peace-process/> accessed 12 March 2019.

30. Ulster Unionist Party, 'Submission by the Ulster Unionist Party to the Northern Ireland Office Consultation Paper' (October 2018), para $17.4<\mathrm{https}$ ://uup.org/assets/images/uup\% 20nio\%20consultation\%20response\%20legacy\%20of\%20past.pdf $>$ accessed 8 March 2019. 
truth recovery process. ${ }^{31}$ It differs also from previous writings by legal scholars on Northern Ireland's metaconflict, which have largely focused on the United Kingdom's resistance to the application of international humanitarian law. ${ }^{32}$

The term Unionist is used to denote the mainstream of the Protestant Unionist Loyalist community that is committed to Northern Ireland remaining within the United Kingdom. This broad community is not homogenous and there are considerable internal tensions, for example, between mainstream Unionists and those who identify as Loyalist. These tensions shape different approaches to the past. For example, Loyalist ex-combatants are generally more willing than mainstream Unionists to 'support the notion that every community has to share responsibility for the past' ${ }^{33}$ Similarly, some Protestant churches have called upon Republican and Loyalist paramilitaries as well as the British and Irish governments to acknowledge and investigate wrongdoing by their operatives. ${ }^{34}$ These differences are significant; however, they are largely sidestepped in this paper, which instead focuses predominantly on the public positions of the main Unionist political parties, the Democratic Unionist Party (DUP) and the Ulster Unionist Party (UUP), together with influential Unionist-aligned institutions, such as the Northern Ireland Retired Police Officers Association (NIRPOA), the Police Federation for Northern Ireland (PFNI), the Orange Order, Unionist victims' organisations, and the smaller Unionist party, the Traditional Unionist Voice (TUV).

The analysis is grounded in socio-legal approaches, including literature on human rights practice, which seeks to understand how actors operationalise, perceive, advocate for, and engage with the idea of human rights. ${ }^{35}$ In particular, it is influenced by the strong strain in this literature exploring how different forms of bias can affect perceptions of the law, ${ }^{36}$ which can in term contribute to (counter)-activism by rightwing groups on human rights issues. ${ }^{37}$ As alluded to above, this article is also

31. Cheryl Lawther, Truth, Denial and Transition: Northern Ireland and the Contested Past (Routledge, Abingdon 2014); Kirk Simpson, Unionist Voices and the Politics of Remembering the Past in Northern Ireland (Palgrave Macmillan, Basingstoke/New York 2009).

32. Campbell (n 27); Campbell et al (n 25).

33. Lawther (n 31) 46.

34. Presbyterian Church in Ireland, 'Response of the Council for Public Affairs of the Presbyterian Church in Ireland to the Northern Ireland Office Consultation Paper: "Addressing the Legacy of Northern Ireland's Past"' (September 2018) <http://www.presbyterianireland.org/getmedia/ 1fc495ed-1f47-4835-b9aa-c01df5d11a13/PCI_Legacy_Consultation_Response_(FN)_20181001. pdf.aspx> accessed 8 March 2019.

35. Ron Dudai, 'Rights Choices: Dilemmas of Human Rights Practice' (2014) 6 Journal of Human Rights Practice 389.

36. Patricia Ewick and Susan S Silbey, The Common Place of Law: Stories from Everyday Life (University of Chicago Press, Chicago/London 1998); Patricia Ewick and Susan Silbey, 'Narrating Social Structure: Stories of Resistance to Legal Authority' (2003) 108 American Journal of Sociology 1328; Stuart A Scheingold, The Politics of Rights: Lawyers, Public Policy, and Political Change (2nd edn, University of Michigan Press, Ann Arbor 2004); William Haltom and Michael McCann, Distorting the Law: Politics, Media, and the Litigation Crisis (University of Chicago Press, Chicago/London 2004).

37. David S Meyer and Suzanne Staggenborg, 'Movements, Countermovements, and the Structure of Political Opportunity' (1996) 101 American Journal of Sociology 1628; Marc Dixon, 'Movements, Countermovements and Policy Adoption: The Case of Right-to-Work Activism' (2008) 87 Social Forces 473; Ron Dudai, 'Entryism, Mimicry and Victimhood Work: The Adoption of Human Rights Discourse by Right-Wing Groups in Israel' (2017) 21 International Journal of Human Rights 866. 
informed by interdisciplinary scholarship on metaconflicts, collective memory and communal approaches to law.

Drawing on these bodies of academic work, the article presents the findings of a qualitative analysis of the publicly available submissions made by Unionist political parties and aligned organisations to an official consultation and parliamentary inquiries relating to dealing with the past in Northern Ireland, which were conducted during 2018. ${ }^{38}$ These consultations were:

1. The Northern Ireland Office Consultation on Addressing the Legacy of Northern Ireland's Past (NIO Consultation), which invited responses on a draft Bill that is intended to provide the legislative basis to implement the 2014 Stormont House Agreement proposals to establish a comprehensive approach. If implemented, these proposals would lead to the creation of a Historical Investigations Unit, to review cases of unsolved Troubles-related deaths, and, if appropriate, refer cases for prosecution; an Independent Commission on Information Retrieval to enable families to seek and privately receive information related to a relative's Troubles-related death; an Oral History Archive; and an Implementation and Reconciliation Group to oversee the other mechanisms, to promote reconciliation, and to commission academic research on themes and patterns of violence that occurred during the Troubles. ${ }^{39}$

2. The House of Commons Northern Ireland Affairs Committee Inquiry on Consultation on the Stormont House Agreement (NIAC Inquiry), which invited stakeholders to comment on the resources, the implementation timetable, stakeholder engagement and remit of the NIO's consultation on the draft Bill to implement the Stormont House Agreement. ${ }^{40}$

3. The House of Commons Defence Committee Inquiry on Statute of Limitations Veterans Protection (Defence Committee Inquiry), which invited submissions on methods to 'protect' former service personnel from 'the spectre of investigation and re-investigation for events that happened many years, and often decades, earlier'. ${ }^{41}$

Where appropriate, this primary data is supplemented by academic literature, official documents, NGO reports, and media articles relating to dealing with the past in Northern Ireland. In addition, the framing of the research question and the themes of analysis are informed by my experience of working with academic and civil society

38. The submissions to the parliamentary committees are published on the UK Parliament website. Submissions to the NIO consultation are only publicly available when the authors choose to put them online. In relying on publicly available submissions, I am focusing on where Unionists articulate positions rather than where they engage in silence. Lawther has cogently argued that Unionist silence may be a strategic choice, a form of communication, and a choosing not to know. See Lawther (n 31) 37.

39. Northern Ireland Office, 'Addressing the Legacy of Northern Ireland's Past' (11 May 2018) $<$ https://www.gov.uk/government/consultations/addressing-the-legacy-of-northern-irelands-past> accessed 5 March 2019.

40. House of Commons Northern Ireland Affairs Committee, 'Consultation on Stormont House Agreement Inquiry' (24 May 2018) <https://www.parliament.uk/business/committees/ committees-a-z/commons-select/northern-ireland-affairs-committee/inquiries/parliament-2017/ consultation-stormont-house-agreement-inquiry-launch-17-19/> accessed 5 March 2019.

41. House of Commons Defence Committee, 'Statute of Limitations - Veterans Protection Inquiry' <https://www.parliament.uk/business/committees/committees-a-z/commons-select/ defence-committee/inquiries/parliament-2017/inquiry13/> accessed 5 March 2019. 
colleagues to inform efforts to address the legacy of Northern Ireland's past in a human rights compliant manner. ${ }^{42} \mathrm{I}$ am also influenced by my involvement in the Executive of the Committee on the Administration of Justice, an independent human rights organisation based in Belfast, of which I have been the Chairperson since 2014.

The article begins in Section 2 by outlining the main communal narratives of the causes of and responsibilities for the violence committed during the Troubles. It then focuses in Section 3 on Unionist perceptions of human rights actors and activism. It argues that while human rights campaigners in Northern Ireland use human rights principles and legal standards to emphasise the objectivity and neutrality of their work, they have nonetheless been viewed as politically partisan by Unionists, which in turn shapes Unionist perceptions of demands for greater truth and accountability for past violations. Section 4 analyses Unionist strategies of engagement with and resistance to human rights obligations to investigate. This analysis is structured around four themes: deploying legal concepts to bolster metaconflict narratives; selectivity in the invocation of human rights standards; requiring investigative decisions to be taken on the basis of 'balance'; and rejecting the application of human rights law to crimes committed by members of the UK armed forces during the Troubles. In Section 5 the article concludes that the Northern Irish experience demonstrates that in deeply divided societies, law is not always viewed as politically neutral and objective. Instead, the selection of applicable international legal standards, the manner in which they are interpreted, and the weight attached to them by diverse actors can reflect wider political contestations. Thus, through subtle and shifting processes the use of international law is framed by the local context.

\section{COMMUNAL NARRATIVES OF THE CAUSES OF AND RESPONSIBILITIES FOR TROUBLES-RELATED VIOLENCE}

Where metaconflicts exist, rival communities lay claim to the historicity of their preferred narratives of the past, but are unwilling to subject the past to rigorous and critical historical analysis. Instead, political actors may appeal to the past to validate their contemporary positions. ${ }^{43}$ At times, this resembles a mythico-history-building exercise in which the past is recast or reinterpreted in both political and moral terms. Such exercises are intended to create or reify social and political categories in ways that distinguish between good and evil, innocence and guilt, and lawful or morally justifiable violence carried out to protect the community and criminal or unjustifiable violence. ${ }^{44}$ Actors who are waging such forms of metaconflict often engage in cognitive dissonance, in which facts are filtered, prioritised or overlooked to fit with preferred political narratives and contemporary political goals. ${ }^{45}$ As a result, within rival communities radically divergent historical narratives can emerge in which each community remembers the harms

42. A key part of this work has been the creation of a 'Model Bill' on the implementation of the Stormont House Agreement. My colleagues Kieran McEvoy and Anna Bryson have reflected on our use of international law in this process in Kieran McEvoy and Anna Bryson, 'Justice, Truth and Oral History: Legislating the Past "from Below" in Northern Ireland' (2016) 67 Northern Ireland Legal Quarterly 67.

43. Lemarchand (n 10) 19.

44. Liisa H Malkki, Purity and Exile: Violence, Memory, and National Cosmology among Hutu Refugees in Tanzania (University of Chicago Press, Chicago/London 1995) 54.

45. Stanley Cohen, States of Denial: Knowing About Atrocities and Suffering (Polity Press, Cambridge/Malden 2001) 159, 266. 
experienced by its members, but struggles to recognise harms experienced by others. As Lemarchand observed in relation to Burundi, "what emerges from the record of official pronouncements and mythicohistories is not pure invention but rather an attempt to embellish or demonize the past to make it consistent with present or future objectives' ${ }^{46}$ Similar processes can be observed in contestations over Northern Ireland's past.

Although division over Northern Ireland's constitutional status has long been at the centre of political violence in Ireland and Northern Ireland, there are particularly strong disagreements over the causes of violence that took place between 1968 and $1998 .{ }^{47}$ Unionist narratives on Northern Ireland's past portray the period from the creation of the Parliament of Northern Ireland in 1921 to the outbreak of the Troubles as a time when 'Catholics and Protestants co-existed peacefully and in a friendly manner' ${ }^{48}$ For Unionists, the peace and social cohesion was violently disrupted by Republican paramilitaries intent on using violence to undermine Northern Ireland's position within the United Kingdom. This narrative contrasts strongly with Nationalist and Republican memories of the pre-Troubles period, which point to the long history of British colonial rule in Ireland, and systemic sectarian discrimination in State institutions dominated by the Ulster Unionist Party - all of which was underpinned by emergency legislation and a police force, which saw policing of its potentially seditious Catholic minority as its key function. ${ }^{49}$ From such a perspective, Republican violence was a response to the rights violations routinely endured by the Catholic minority, which it was argued could only be remedied by uniting Northern Ireland with Ireland. Thus, human rights discourse has been a central component of Nationalist narratives of the causes of the Troubles. Smithey argues that, as a result, for Unionists, human rights language 'was considered inappropriate under the totalising and polarising logic of ethnopolitical division. Once it was associated with nationalism, it was tainted' ${ }^{50}$ As the next section explores, this association of rights with nationalism contributed to a position among Unionists that if they invoked rights to criticise the State, it would amount to a betrayal of their community.

From these rival explanations of the causes of the violence emerge contrasting attributions of responsibility. Republicans have consistently contended that their paramilitaries were waging an armed conflict against the United Kingdom and that the British State should be seen as a party to the conflict. For Unionists, the Troubles should be understood as terrorism and criminality waged by paramilitary groups, not an armed conflict. From this, Unionists contend that the State, encompassing where appropriate the Unionist-dominated devolved institutions prior to the imposition of direct rule in 1972 and the United Kingdom, should not be viewed as a protagonist to an armed conflict. Instead, they argue that the State's actions should be understood as those of a democratic State acting to uphold the rule of law and human rights in the face of a terrorist threat. Thus, under this narrative, 'the State had no primary institutional responsibility, but merely responded to inter-communal conflict' ${ }^{51}$ Further, this narrative

46. Lemarchand (n 10) 19.

47. Sarah Jankowitz, "The "Hierarchy of Victims" in Northern Ireland: A Framework for Critical Analysis' (2018) 12 International Journal of Transitional Justice 216.

48. Simpson (n 31) 39.

49. See eg Michael Farrell, Northern Ireland: The Orange State (2nd edn, Pluto Press, London 1980); Michael Farrell, Arming the Protestants: The Formation of the Ulster Special Constabulary and the Royal Ulster Constabulary, 1920-27 (Pluto Press, London 1983).

50. Lee A Smithey, Unionists, Loyalists, and Conflict Transformation in Northern Ireland (OUP, New York 2011) 142.

51. Bell (n 22) 1140. 
holds that during the Troubles, the Royal Ulster Constabulary (RUC) and the British armed forces acted to defend Northern Ireland and the Union with Great Britain from terrorism and to uphold the rule of law, and in doing so, often heroically endured physical loss and sacrifice. ${ }^{52}$ On this basis, Unionists maintain that responsibility for the onset of the Troubles and for the violence that resulted rests with paramilitaries, who should be the sole or primary focus of efforts to deal with the past.

The understanding of the State as democratic and law-abiding during the Troubles complicates the application of the concept of 'transition' to Northern Ireland in the post-Good Friday Agreement period. ${ }^{53}$ For some Unionists, the concept of 'transition' inherent in transitional justice is inapplicable. This view is well illustrated in NIRPOA's submission to the NIAC Inquiry:

Both our major universities have produced 'experts' who use language which betrays their bias ('the conflict', 'combatants' etc) and who seem to imagine that our recent history and the conduct of our government is in some way comparable with that of certain regimes in the Far East, South

America or the Republic of South Africa. The very use of the term 'transitional justice' indicates a perverse starting point for their deliberations. ${ }^{54}$

As the next section explores, resistance to transitional justice language and mechanisms among the Unionist community can also be tied to their perceptions of human rights law and human rights actors, which are in themselves affected by the metaconflict.

\section{OBJECTIVITY, NEUTRALITY AND POLITICS WITHIN HUMAN RIGHTS WORK IN NORTHERN IRELAND}

For some commentators, '[h]uman rights are inherently political; to embrace or contest them is to take sides on questions of power', ${ }^{55}$ and some human rights defenders may be motivated by and publicly acknowledge the avowedly political objectives of their work. ${ }^{56}$ However, it is more common for human rights defenders to downplay the politics of their practice. Instead, they use the language of law to position themselves as authoritative voices that operate in a neutral, non-partisan and non-political manner in conducting objective and technical analysis on the basis of universal legal standards. ${ }^{57}$

52. Lawther (n 31) 132.

53. Fionnuala Ní Aoláin and Colm Campbell, 'The Paradox of Transition in Conflicted Democracies' (2005) 27 Human Rights Quarterly 172.

54. Northern Ireland Retired Police Officers Association, 'Written Evidence Submitted by the Northern Ireland Retired Police Officers Association (SHA0035)' (9 June 2017) <http:// data.parliament.uk/writtenevidence/committeeevidence.svc/evidencedocument/northern-irelandaffairs-committee/consultation-on-implementation-of-the-stormont-house-agreement/written/ 86568.html> accessed 8 March 2019.

55. Michael Goodhart, Human Rights: Politics and Practice (3rd edn, OUP, New York 2016) 5. 56. See eg Michael Sfard, 'The Price of Internal Legal Opposition to Human Rights Abuses' (2009) 1 Journal of Human Rights Practice 37. See also the series of case study reports from the Lawyers, Conflict and Transition project that provided an overview of the role of lawyers as political actors in South Africa, Tunisia, Chile, Israel, Palestine and Cambodia: Lawyers, Conflict and Transition, 'Outputs' <https://lawyersconflictandtransition.org/outputs/> accessed 11 March 2019.

57. See eg Amnesty International, 'Who We Are' <https://www.amnesty.org/en/who-weare/> accessed 22 January 2019: 'We are independent of any political ideology, economic 
In doing so, human rights organisations may refrain from identifying themselves with any political party or ethnic group within society. ${ }^{58}$ Within democratic States, where there is broad political support for human rights, it is often possible for human rights organisations to indeed operate and be seen to operate in a less overtly political manner. However, in more repressive or divided contexts, the politics of advocating for rights often becomes more visible and contested. This is particularly the case where human rights obligations to investigate and prosecute are applied to politically motivated past crimes. ${ }^{59}$ As this section explores, with reference to the Committee on the Administration of Justice (CAJ), which has been described as the 'principal human rights NGO' in Northern Ireland, ${ }^{60}$ such political contestation over human rights has been present within Northern Ireland since the onset of the Troubles. ${ }^{61}$ Unionist perceptions of human rights actors have in particular been shaped by the role of human rights actors in holding the State to account and the decision of some human rights actors in Northern Ireland to refrain from monitoring paramilitary violence. This section argues Unionist perceptions of human rights fed into their perceptions of contemporary debates on dealing with the past.

Unionist perceptions of human rights actors must be understood within the context of the significant role that the European Court of Human Rights (ECtHR) has played in advancing approaches to dealing with the past in Northern Ireland. During and after the conflict, victims and human rights campaigners brought cases to the ECtHR relating to allegations of State responsibility for conflict-related deaths either directly or through collusion with Loyalist paramilitaries. This strategic litigation resulted in particular in the Court's 2001 unanimous judgments in the McKerr group of cases that the UK had violated its procedural obligations under Article 2 of the Convention on the Right to Life (read in conjunction with Article 1) when it had failed to undertake effective, independent, prompt and transparent investigations. ${ }^{62}$ The Court's judgments

interest or religion. No government is beyond scrutiny. No situation is beyond hope'. See also Human Rights Watch, 'About'<https://www.hrw.org/about> accessed 22 January 2019: 'To ensure our independence, we do not accept government funds, directly or indirectly, or support from any private funder that could compromise our objectivity and independence. We do not embrace political causes, are non-partisan, and maintain neutrality in armed conflict'. For a critique of the objectivity in their work, see Louise Mallinder, 'Law, Politics and FactFinding: Assessing the Impact of Human Rights Reports' (2010) 2 Journal of Human Rights Practice 166.

58. Vijay K Nagaraj and Shermal Wijewardene, “"A Very Highly Political Job”: Human Rights Practice, "The Political", and Practitioners' Dilemmas in Sri Lanka' (2014) 6 Journal of Human Rights Practice 399.

59. For a detailed exploration of these tensions with respect to the work of human rights lawyers in transitional settings, see Kieran McEvoy, 'Cause Lawyers, Political Violence and Professionalism in Conflict' (forthcoming).

60. Eitan Felner, 'Human Rights Leaders in Conflict Situations: A Case Study of the Politics of "Moral Entrepreneurs"” (2012) 4 Journal of Human Rights Practice 57.

61. Recently declassified files show that in $1994 \mathrm{CAJ}$ 's ability to use "international force" in an attempt to bring pressure to bear on the government' was a 'regular irritant' by the NIO. However, the files also make clear that the NIO recognised that CAJ was 'firmly opposed to the use of violence to achieve political goals' and that they were not 'in any way a sinister grouping'. See Sam McBride, 'Declassified Files: NIO Said CAJ and Leading Human Rights Academic were "Biased"', Newsletter (3 January 2019) <https://www.newsletter.co.uk/news/ declassified-files-nio-said-caj-and-leading-human-rights-academic-were-biased-1-8756349> accessed 22 January 2019.

62. See eg Jordan v UK (2003) 37 EHRR 2, paras 105-109. 
were valuable in acknowledging the State's responsibility for the killings and clarifying the State's obligations to investigate and provide remedies. In addition, in accordance with Article 46 of the European Convention on Human Rights (ECHR), the UK is obliged to abide by the Court's judgments and its compliance is supervised by the Council of Europe's Committee of Ministers. Through its engagement with this compliance process, the British government gradually formulated a policy, known as the 'package of measures', to deal with the past in which existing institutions were reformed and new institutions were created. ${ }^{63}$ The institutions comprising this package of measures are coroner's inquests, public inquiries, police-led investigations (previously the Historical Enquiries Team and now the Police Service of Northern Ireland (PSNI) Legacy Investigations Branch), and the historical investigations of the Police Ombudsman. The ECHR litigation thus provided a catalyst for the development of dealing with the past mechanisms in Northern Ireland as well as a mechanism for routine international scrutiny of the UK's compliance with its obligations, a process into which human rights actors are able to submit 'shadow' reports. This demonstrates that human rights law, institutions and actors have played a significant role in pressuring the United Kingdom to investigate Troubles-related offences.

Turning now to Unionist perceptions of local human rights actors, CAJ provides a useful example of a local non-governmental organisation (NGO) that has consistently sought to safeguard its objectivity and neutrality, but has nonetheless been viewed with suspicion by some Unionist political groups. In the midst of the Troubles, CAJ was founded in 1981 as an 'independent non-governmental organisation' to ensure that local, regional and national government complies with its responsibilities under international human rights law. From its inception, the 'CAJ was founded on the belief that it could only secure the desired impact if the organisation developed and maintained a reputation for acting in an independent, politically impartial, objective and measured way' ${ }^{64}$ For CAJ, objectivity has multiple parts. Firstly, the organisation 'takes no position on the constitutional status of Northern Ireland' ${ }^{65}$ Secondly, CAJ 'is firmly opposed to the use of violence for political ends' ${ }^{66}$ Thirdly, it draws its membership from across the community ${ }^{67}$ Finally, CAJ bases its work firmly within the international human rights law framework.

CAJ's exclusive adherence to human rights law contributed to its decision to monitor only State violence and refrain from monitoring paramilitary activities. When CAJ was created in 1981, all major human rights organisations focused solely on monitoring the responsibilities of States to promote, protect and fulfil individual rights. However, leading international human rights organisations shifted their position around the time of the end of the Cold War and began to monitor non-State armed groups,${ }^{68}$ but, in doing so, they applied the framework of international humanitarian

63. Committee on the Administration of Justice, 'The Apparatus of Impunity? Human Rights Violations and the Northern Ireland Conflict: A Narrative of Official Limitations on PostAgreement Investigative Mechanisms' (CAJ, Belfast 2015) 2.

64. Maggie Beirne, A Beacon of Hope: The Story of CAJ (CAJ 2016) 38.

65. Committee on the Administration of Justice, 'About CAJ' <https://caj.org.uk/about/> accessed 13 March 2019.

66. Ibid.

67. Ibid.

68. Amnesty International Press Statement (7 September 1991), cited in Beirne (n 64) 46: 'We continue to hold governments directly responsible for the protection of human rights under international law and violations by governments will always remain the focus of our work, but we must confront atrocities committed by groups like the Tamil Tigers in Sri Lanka and Sendero 
law (IHL) rather than international human rights law. The change in the international NGOs' positions caused CAJ to reflect on whether to follow their lead. After extensive internal debate, the decision was finally taken by an overwhelming majority of CAJ members in late 1991 to continue to refrain from monitoring paramilitary violence.

The organisation's newsletter reported that this decision was motivated by concerns that applying IHL to the Northern Ireland conflict 'would offer legitimacy to paramilitary protagonists and actions and that the notion of a "legitimate target" ran contrary to the organisation's essentially pacifist position of complete opposition to political violence'. ${ }^{69}$ In addition, there were concerns that applying the concept of a legitimate target 'would lead to accusations of selective condemnation in accepting attacks on the security forces'.$^{70}$ As McEvoy argued, adopting the position that attacks on State targets were legitimate provided they complied with IHL could have meant that Republican violence was 'more likely (although by no means universally) to be deemed permissible by humanitarian law than that carried out by Loyalists'. ${ }^{71}$ Based on these cumulative concerns, CAJ members adopted the position that monitoring paramilitary violence under IHL could run the risk of compromising the organisation's objectivity. ${ }^{72}$ Further, given that international human rights law at that point had little provision for monitoring non-State actors, ${ }^{73}$ it would have not been possible for CAJ to apply the human rights framework to their actions in a rigorous manner. ${ }^{74}$ A similar position was adopted by the Northern Ireland Human Rights Commission after its creation in $1999 .{ }^{75}$

Unionists suffered more from the violence of paramilitary actors than from violence committed by State actors, and they interpreted the decision of CAJ and other human rights actors not to monitor paramilitary violence as an indicator that they were biased and aligned to Nationalism. ${ }^{76}$ This position was reinforced by viewing the position of human rights actors alongside Sinn Féin's longstanding position 'that only the state

Luminoso in Peru'. See also Peter R Baehr, 'Amnesty International and its Self-Imposed Limited Mandate' (1994) 12 Netherlands Quarterly of Human Rights 5. Human Rights Watch made a similar decision in the 1980s. See Robert Kogod Goldman, 'International Humanitarian Law: Americas Watch's Experience in Monitoring Internal Armed Conflicts' (1993) 9 American University International Law Review 49. Examples of resulting reports on Northern Ireland include Helsinki Watch, 'Human Rights in Northern Ireland' (1991); Amnesty International, 'Political Killings in Northern Ireland' (1994).

69. CAJ, JustNews (December 1991) cited in Kieran McEvoy, 'Human Rights, Humanitarian Interventions and Paramilitary Activities in Northern Ireland' in Colin J Harvey (ed), Human Rights, Equality and Democratic Renewal in Northern Ireland (Hart Publishing, Portland 2001) 215, 244.

70. Ibid.

71. McEvoy (n 69) 226.

72. Felner (n 60).

73. International law has now of course evolved on this issue. See generally Andrew Clapham, Human Rights Obligations of Non-State Actors (OUP, Oxford 2006). See also Ergi v Turkey App no 23818/94 (ECtHR, 28 July 1998); Aliyeva and Aliyev v Azerbaijan App no 35587/08 (ECtHR, 31 July 2014); Menson v UK App no 47916/99 (ECtHR, 6 May 2003).

74. For a discussion of how similar debates played out in the international human rights movement, see Ron Dudai and Kieran McEvoy, 'Thinking Critically About Armed Groups and Human Rights Praxis' (2012) 4 Journal of Human Rights Practice 1.

75. Peter Munce, 'Unionism and the Northern Ireland Human Rights Commission 1999-2005: Hostility, Hubris and Hesitancy' (2014) 29 Irish Political Studies 194.

76. Ibid 204. 
and state agencies may commit human rights violations while actions by non-state actors are a matter for criminal law to deal with' ${ }^{77}$

In addition to the criticism of the failure of human rights NGOs to monitor paramilitary violence, Unionists have responded negatively to human rights work that seeks to hold the State to account. Unionists generally view the State as a benign, and even deified, entity. As a result, Unionists are often resistant to measures that seek to restrict the exercise of governmental power, which has informed their resistance to economic and social rights being considered legally enforceable human rights. ${ }^{78}$ In addition, Unionist self-identity is closely aligned to the State. Thus, Unionists resist the work of $\mathrm{CAJ}$ and other human rights practitioners in monitoring and criticising the State, even though such monitoring is conducted in accordance with international human rights treaties, which have been ratified by the UK government and adverse rulings from the ECtHR, with which the UK government has committed itself to complying. Thus, Unionists view calls to investigate State abuses or to adopt measures to curb them in the future 'as being antithetical to their interests' ${ }^{79}$ For example, the current DUP leader and law graduate, Arlene Foster, writing in 2003, looked back on the time when Unionists dominated government in Northern Ireland to say that traditionally it would have been something of an anathema for grassroots members of Unionism to challenge the state with a claim for their human rights' ${ }^{80}$ She continued that 'human rights is like a foreign language to most' ${ }^{81}$ More starkly, DUP Member of the Legislative Assembly (MLA) Peter Weir stated that Unionists view human rights as 'betrayal' as they understand it to mean 'taking some degree of legal action either directly against the state or an organ of the state, particularly the security forces' ${ }^{82}$ However, as the later sections demonstrate, this perception that taking legal action against the State would be disloyal does not equate to a reluctance among Unionists to criticise the UK government's actions when they believe the government is acting in a manner that is contrary to Unionist interests.

Unionist self-identification with the State means that actions that are perceived as anti the British State are also perceived as anti-Unionist. From this, some Unionist political actors have asserted that human rights actors were biased against Unionism. For example, in 2007, DUP MLA Michelle McIlveen stated: 'The CAJ is no friend of unionism ... it styles itself as an independent, cross-community, human rights organisation, but its documents reek of anti-unionism and anti-Britishness' ${ }^{83}$ This perception

77. Omar Grech, Human Rights and the Northern Ireland Conflict: Law, Politics and Conflict 1921-2014 (Routledge, Abingdon/New York 2017) 215-216.

78. Anne Smith and Eithne McLaughlin, 'Delivering Equality: Equality Mainstreaming and Constitutionalisation of Socio-Economic Rights' (2010) 61 Northern Ireland Legal Quarterly 93, 116-117; Peter Munce, 'Unionists as "Court Sceptics": Exploring Elite-Level Unionist Discourses about a Northern Ireland Bill of Rights' (2013) 15 The British Journal of Politics and International Relations 647, 659.

79. Stephen Livingstone and Rachel Murray, Evaluating the Effectiveness of National Human Rights Institutions: The Northern Ireland Human Rights Commission with Comparisons from South Africa, University of Bristol and Queen's University Belfast (2005) 51 <http://uir. ulster.ac.uk/31721/1/NHRI_report.pdf> accessed 14 March 2019.

80. Arlene Foster, 'Protestants Need Rights Explained to Them' (2003) 411 Fortnight 12, 12. 81. Ibid 13.

82. Cited in Munce (n 75) 206-207.

83. Northern Ireland Assembly, 'Official Report Monday 15 October 2007' (15 October 2007) $<$ http://www.niassembly.gov.uk/assembly-business/official-report/reports-07-08/15-october2007/> accessed 22 January 2019. 
of anti-Unionist bias has prompted some Unionists to argue that human rights organisations were aligned to Nationalism. For example, in 2001, the DUP MLA Sammy Wilson decried CAJ as 'a Nationalist front organisation'. ${ }^{84}$ Thus, through its criticism of the State, for some Unionists, human rights work became associated with Nationalist political agendas. Unionist efforts to challenge the objectivity of human rights organisations by accusing them of being politically or ideologically motivated has resonances with strategies employed by pro-State actors in other conflicted or repressive contexts. Indeed, Cohen highlighted how in countries such as Peru, Israel and Sri Lanka, such strategies to 'shoot the messenger' are among some of the 'simplest' forms of denial. ${ }^{85}$

This scepticism towards specific human rights actors and methods of working does not equate to an absolute rejection of human rights among Unionists. For example, in 2017, former DUP MLA Nelson McCausland argued that Sinn Féin used 'the language of human rights and a rights-based approach to fight its "war by another means" before arguing with respect to the Unionist community " $[\mathrm{t}]$ hat does not mean that we reject the principles of equality and human rights. In themselves, they are valuable concepts'. ${ }^{86}$ In addition, in the post-Agreement period, there have been some examples, where Unionist-orientated organisations have tried to embrace the language of human rights. For example, the Orange Order has invoked the right to freedom of assembly under the ECHR in arguing that its members should be able to march down their traditional routes. ${ }^{87}$ In addition, the Orange Order has described restrictions on marches that are objected to by local residents as 'a denial of basic civil liberties'. ${ }^{88}$ Despite continuing to refer to human rights language when their human rights orientated demands were rejected, Foster indicated that where Unionist efforts to use human rights have not achieved the outcome they desired, it has increased their sense of being marginalised or victimised by the human rights agenda. ${ }^{89}$

From the above, we can see that although Unionists do not reject the language of human rights wholesale, they feel that human rights have tended to be used in a manner that is detrimental to their interests. This general scepticism towards human rights has in turn informed their attitudes towards actors who are campaigning for truth, justice and reparations in relation to the legacy of the Troubles, as well as towards the role of international human rights law in dealing with the past. With respect to actors, Northern Ireland is a small place and many of the voices that call for approaches to deal with the past come from academics and practitioners within the human rights community, including CAJ. It is therefore unsurprising that Unionist concerns over the impartiality of human rights have also shaped how they perceive actors working to deal with the legacy of the Troubles in Northern Ireland. For example, the UUP's submission to the NIAC Inquiry sought to conflate the work of human rights defenders and victims' groups in calling for accountability for past crimes with what they perceive as 'partisan', Republican efforts to 'rewrite history' in order to portray the State as responsible for

84. Northern Ireland Assembly, 'Northern Ireland Assembly Archive Site' (25 September 2001) <http://archive.niassembly.gov.uk/record/reports/010925d.htm> accessed 8 March 2019. 85. Cohen (n 45) 112.

86. Nelson McCausland, 'Where was Sinn Fein's Concern for Human Rights on Bloody Friday, at Claudy, La Mon or Enniskillen?', Belfast Telegraph (6 July 2017) <https://www.belfasttelegraph. co.uk/opinion/columnists/nelson-mccausland/where-was-sinn-feins-concern-for-human-rights-onbloody-friday-at-claudy-la-mon-or-enniskillen-35900315.html> accessed 13 March 2019.

87. Smithey (n 50) 142-143.

88. The Orange Order, 'A Parading Tradition' <http://www.grandorangelodge.co.uk/parading\#. XEi6W1z7TIU> accessed 23 January 2019.

89. Foster (n 80). 
abusing human rights. ${ }^{90}$ In its submission to the NIO Consultation, the TUV went further by characterising the NIO's draft bill as being designed 'to satisfy the demands of the Republican movement', rather than being motivated by a genuine concern for victims. ${ }^{91}$ It is against this backdrop of Unionist approaches to human rights that we now move to interrogating the specific strategies employed by Unionists when engaging with the UK's international human rights obligations to investigate legacy offences.

\section{UNIONIST STRATEGIES OF ENGAGEMENT WITH HUMAN RIGHTS LAW}

This section explores how the metaconflict shapes the strategies used by Unionists in critiquing how international human rights standards have been applied in the work of existing mechanisms to deal with the past and resisting particular interpretations in light of the new institutions that have been proposed in the NIO Consultation. These strategies are: deploying legal concepts to buttress metaconflict narratives; selectivity in the invocation of human rights law; requiring investigative decisions to be taken on the basis of 'balance'; and, finally, rejecting the application of human rights law to the actions of members of the UK armed forces during the Troubles. The Unionist articulations of some of these strategies in the recent consultation reflect longstanding positions within Unionism. In contrast, other strategies have emerged more recently, primarily in response to the opening of criminal investigations against former UK service personnel.

\subsection{Deploying legal concepts to buttress metaconflict narratives}

Within the literature on social movements and human rights practice, there is a general consensus that social actors are drawn to the legal language and institutions as law has

90. Ulster Unionist Party, 'Written Evidence Submitted by Ulster Unionist Party' Defence Committee Inquiry (24 July 2018) <http://data.parliament.uk/writtenevidence/committeeevidence. svc/evidencedocument/defence-committee/statute-of-limitations-veterans-protection/written/ 87043.html> accessed 8 March 2019: 'In their efforts to rewrite history Republicans are assisted in their efforts by a plethora of self-styled human rights lawyers and pro-Republican victims' groups. They are partisan, with no interest in the truth but every interest in casting the British State, the Police and the Army as being in the wrong'. The perception that human rights activists are politically motivated has also been expressed by members of the Conservative Party. For example, at the 2016 Conservative Party conference, Theresa May spoke about the role of human rights lawyers in pursuing accountability for crimes committed by UK armed forces personnel in Northern Ireland, Iraq and Afghanistan, stating 'We will never again - in any future conflict - let those activist left wing human rights lawyers harangue and harass the bravest of the brave, the men and women of our armed forces'. Cited in Samuel Osbourne, 'Theresa May Speech: Tory Conference Erupts in Applause as PM Attacks "Activist Left Wing Human Rights Lawyers" The Independent (5 October 2016) <https://www.independent.co.uk/news/uk/politics/theresamay-tory-conference-speech-applause-attacks-activist-left-wing-human-rights-lawyers-a7346216. html> accessed 8 March 2019.

91. Traditional Unionist Voice, 'Consultation Paper Addressing the Legacy of Northern Ireland's Past: Response by Traditional Unionist Voice - TUV' <http://tuv.org.uk/wp-content/ uploads/2018/06/Consultation_Paper_Addressing_the_Legacy_of_Northern_Irelan1.pdf> accessed 8 March 2019. 
an inherent power that may benefit their mobilisation, ${ }^{92}$ even where it does not result in courtroom victories. ${ }^{93}$ Law is understood to have the capacity to create cultural meanings and express social norms. It can frame public discourse and shape collective identities. ${ }^{94}$ However, legal meanings are not fixed concepts that are universally understood across social groups. Instead, they are often indeterminate, which allows different social groups to seek to construct their own readings of rights. ${ }^{95}$ Silverstein has argued that 'just as legal meaning constitutes individual and social identity, so too does individual and social identity constitute legal meaning'. ${ }^{96}$ With respect to serious human rights violations, the language of law and criminality can provide cogent labels with which to denounce wrongdoing and to define understandings of victimhood, ${ }^{97}$ even though as Hearty highlights it is erroneous to assume that "criminal law is capable of capturing the full complexity of innocence and blame during conflict' ${ }^{98}$ The rhetorical power of law to condemn or commemorate has meant that Northern Ireland's metaconflict has included disputes over how human rights concepts should be understood and applied. For Unionists, this has included strongly resisting inclusive definitions of who can been considered a victim, while also seeking to apply the legal terminology of genocide and ethnic cleansing to repudiate specific actions of Republican paramilitaries during the conflict. In both instances, Unionist strategies operate on a largely rhetorical level as they do not seek to engage deeply with international human rights standards or institutions to press their claims.

The legal definition of a 'victim and survivor' of a Troubles-related offence can be found in the Victims and Survivors (Northern Ireland) Order 2006, which takes an inclusive approach that enables victimised individuals to be recognised as such irrespective of whether they were also involved in victimising others. This definition is accepted by the main Nationalist and Republican political parties and organisations, however Unionist political parties and organisations have consistently objected to its failure to take into account a person's affiliation or other participation in violence. ${ }^{99}$ For example, in its submission to the NIO Consultation, the DUP stated that the definition was 'unacceptable' arguing that in their opinion 'there is a clear distinction in law between a terrorist perpetrator and their innocent victim. To equate the two is morally wrong and indefensible'. They therefore contended that the UK government should introduce legislative amendments to ensure that the "perpetrator of an unlawful

92. Scheingold (n 36) xxiii.

93. Sally Engle Merry, 'Resistance and the Cultural Power of Law' (1995) 29 Law and Society Review 11, 14.

94. Michael W McCann, Rights at Work: Pay Equity Reform and the Politics of Legal Mobilization (University of Chicago Press, Chicago/London 1994).

95. Scheingold (n 36) xxvii.

96. Helena Silverstein, Unleashing Rights: Law, Meaning and the Animal Rights Movement (University of Michigan Press, Ann Arbor 1996) 9.

97. Jemima Garcia-Godos, 'Victim Reparations in the Peruvian Truth Commission and the Challenge of Historical Interpretation' (2008) 2 International Journal of Transitional Justice 63.

98. Kevin Hearty, 'Victims Who have Done Nothing or Victims Who have Done Nothing Wrong: Contesting Blame and "Innocent Victim" Status in Transitioning Societies' (2019) The British Journal of Criminology <https://academic.oup.com/bjc/advance-article/doi/ 10.1093/bjc/azz017/5372970> accessed 12 March 2019.

99. For analysis of earlier iterations of this debate, see Kevin Hearty, 'Legislating Hierarchies of Victimhood and Perpetrators: The Civil Service (Special Advisers) Act (Northern Ireland) 2013 and the Meta-Conflict' (2016) 25 Social and Legal Studies 333. 
act' cannot be included within the definition. ${ }^{100}$ A similar position was adopted by the UUP in its submission to the same consultation, which stated:

It is both ludicrous - and morally indefensible - that someone who made a conscious choice to plant a bomb or set out to shoot someone, and who was injured in the process, should be classed as a victim in the same manner as someone who was blown up or shot whilst out shopping or enjoying an evening out. ${ }^{101}$

This position is also evident in the submissions made by Unionist-aligned groups. ${ }^{102}$ In calling for the legislative amendment of the statutory definition of victimhood, Unionists frame their arguments in moral terms and in accordance with their preferred narrative of Northern Ireland's past. ${ }^{103}$ This approach has resonances with international experiences of resistance to rights by conservative groups who seek to "challenge egalitarian inflections of rights and propose culturally resonant alternatives' 104 and political contestation over definitions of victimhood are common to many postconflict societies. ${ }^{105}$ Through arguing for legislative change, Unionists are seeking to shape socio-political understandings of victimhood. However, these assertions are often made with reference to the longstanding political standoff over the provision of a pension to persons who were seriously injured during the Troubles. In this context, narrowing the definition could have legal consequence through restricting who can access reparations or seek other remedies for violations of their legally enshrined rights. ${ }^{106}$

If Unionist political parties were primarily concerned with restricting the legal consequences of the victim definition, they could benefit from engaging with the 2016 report by the UN Special Rapporteur on Truth, Justice, Reparations and Guarantees of Non-Repetition on his country visit to the United Kingdom. This report observes that in designing reparations programmes, 'most countries steer away from debates over the definition of "victim". ${ }^{107}$ Instead, comparative analysis of approaches in other countries demonstrates a tendency to define 'beneficiaries' of specific reparations programmes, ${ }^{108}$ with the possibility that distinct forms of reparations could be

100. Democratic Unionist Party, 'Response to the Government Consultation on "Addressing the Legacy of Northern Ireland's Past"' (5 October 2018) <http://www.mydup.com/images/uploads/ publications/DUP_Response_to_NIO_Legacy_Consultation.pdf> accessed 8 March 2019.

101. Ulster Unionist Party (n 30) para 1.7.

102. Ulster Human Rights Watch, 'Written Evidence Submitted by Ulster Human Rights Watch (SHA0036)', submission to the NIAC Inquiry <http://data.parliament.uk/writtenevi dence/committeeevidence.svc/evidencedocument/northern-ireland-affairs-committee/consulta tion-on-implementation-of-the-stormont-house-agreement/written/86758.pdf $>$ accessed 13 March 2019. See also The Orange Order, 'New Thinking Required on Legacy, Says Order', Orange News (5 October 2018) <http://www.grandorangelodge.co.uk/news.aspx?id=103501\#. XIo2ay2cZQI> accessed 8 March 2019. The Orange Order does not appear to have published its full submission to the NIO online.

103. Lawther (n 31).

104. Scheingold (n 36) xxxiv.

105. Kieran McEvoy and Kirsten McConnachie, 'Victimology in Transitional Justice: Victimhood, Innocence and Hierarchy' (2012) 9 European Journal of Criminology 527; Erica Bouris, Complex Political Victims (Kumarian Press, Bloomfield 2007).

106. Hearty (n 99) 336-337.

107. UNGA, 'Report of the Special Rapporteur on the Promotion of Truth, Justice, Reparation and Guarantees of Non-Recurrence on his Mission to the United Kingdom of Great Britain and Northern Ireland', UN Doc A/HRC/34/62/Add.1 (17 November 2016) para 73.

108. Ibid paras $73-74$. 
tailored to the needs of different victim communities. ${ }^{109}$ To some degree, such approaches separate socio-political understandings of victimhood from discussions of who is entitled to specific forms of reparations. However, the apparent Unionist objective of contesting the legal definition of victimhood to apportion guilt and innocence could mean that such nuanced approaches are unlikely to find support among Unionists; nor are they likely to find support among Nationalists who favour the existing inclusive definition.

Unionists have also sought to reinterpret and apply international human rights concepts to suit their metaconflict aims when they have described actions of Republican paramilitaries as 'genocide' and 'ethnic cleansing'. Scholars have long understood that these are powerful terms and the consequences of their application 'can slide from' their specific legal meaning 'to a branding of the perpetrators' group as collectively evil', which in turn limits the 'case that a political compromise needs to be found with them'. ${ }^{110}$ Thus, the application of these labels can give rise to both legal and political consequences. The invocation of this language in Northern Ireland has its roots in the late 1980s, when Unionists began to complain about what they viewed as the forced displacement of Protestants from the west of the city of Derry/ Londonderry. ${ }^{111}$ When the conflict in Bosnia-Herzegovina introduced the term 'ethnic cleansing' to the human rights lexicon, ${ }^{112}$ Unionists, such as Member of Parliament (MP) Jeffrey Donaldson, adopted this term and began to use it to describe these demographic shifts. ${ }^{113}$ Unionists have continued to use this terminology throughout the transition. ${ }^{114}$ For example, in 2011, DUP leader Arlene Foster (who was then a minister in the devolved institutions) called on the Irish government to apologise for failing to secure the border during the Troubles and said that 'the Irish government of the 1970s and late 1960s could have done a lot more to stop the campaign of genocide that was happening in Fermanagh, Tyrone, south Armagh and Londonderry'. ${ }^{115}$ In making similar calls, the following year, Foster asserted that the Irish government's

109. Luke Moffett, 'A Pension for Injured Victims of the Troubles: Reparations or Reifying Victim Hierarchy?' (2016) 66 Northern Ireland Legal Quarterly 297.

110. Alex de Waal, 'Reflections on the Difficulties of Defining Darfur's Crisis as Genocide' (2007) 20 Harvard Human Rights Journal 25, 31.

111. Paul Kingsley, Londonderry Revisited: A Loyalist Analysis of the Civil Rights Controversy (Belfast Publications, Belfast 1989).

112. Matthew Lewis and Shaun McDaid, 'Bosnia on the Border? Republican Violence in Northern Ireland During the 1920s and 1970s' (2017) 29 Terrorism and Political Violence 635. See also Gareth I Higgins and John D Brewer, 'The Roots of Sectarianism in Northern Ireland' in Owen Hargie and David Dickson (eds), Researching the Troubles: Social Science Perspectives on the Northern Ireland Conflict (Mainstream Publishing, Edinburgh 2003) 107. 113. Jeffrey Donaldson, 'A Protestant Perspective' (1994) Ulster Review 8.

114. Gillian Halliday, 'UUP Councillor Avoids Investigation Over SF 'Ethnic Cleansing' Jibe', Belfast Telegraph (4 January 2019) <https://www.belfasttelegraph.co.uk/news/northern-ireland/ uup-councillor-avoids-investigation-over-sf-ethnic-cleansing-jibe-37679118.html > accessed 15 March 2019. See also Doug Beattie, 'I Won't Take Offended Rhetoric from a Party with a Callous Heart', Belfast Telegraph (24 October 2017) <https://www.belfasttelegraph.co.uk/ opinion/news-analysis/doug-beattie-i-wont-take-offended-rhetoric-from-a-party-with-a-callousheart-36255338.html> accessed 15 March 2019: 'What happened in that border area was little short of ethnic cleansing, yet nobody was brought to justice'; Ulster Unionist Party (n 30).

115. 'Ministers' Plea to Irish Government over Republican Murder Victims', BBC News (18 November 2011) <https://www.bbc.co.uk/news/uk-northern-ireland-15799085> accessed 15 March 2019 (emphasis added). 
apology must make 'reference to and acknowledge the ethnic cleansing' which took place along the Irish border by the Provisional IRA. ${ }^{116}$

Where ethnic cleansing is committed during a conflict it could be considered a war crime, and where it is systematic and widespread it could constitute a crime against humanity. International criminal law recognises genocide, war crimes, and crimes against humanity as international crimes for which individuals can be held criminally responsible. However, as Lewis and McDaid have demonstrated, Republican actions in relation to Unionist population movements during the Troubles 'fell far short' of the international legal definitions of these crimes. ${ }^{117}$ Perhaps in response to the legal impossibility of their arguments, where Unionists use this language, they invoke it in a rhetorical rather than a legal sense. They use it to demand acknowledgement and apologies, rather than prosecution and punishment. And in using it, they recognise the rhetorical power of these labels through which they seek to control a narrative of violent Republicanism. As a consequence of this positioning, they have not argued that these alleged crimes be subject to criminal investigation. Instead, from the negotiations leading to the Stormont House Agreement they advocated that 'alleged ethnic cleansing in border regions and in interface neighbourhoods' should be the subject of thematic analysis. ${ }^{118}$ This positioning seems to be maintained through the most recent round of consultations. ${ }^{119}$

These examples demonstrate how at times Unionists engage with international human rights law concepts, but, contrary to the principles that human rights should apply equally to all, they seek to reinterpret victimhood in an exclusionary manner. In addition, they invoke concepts such as genocide to settings that do not correspond to the internationally accepted definition of this crime. Through these processes, they seek to challenge and adapt the meaning of human rights concepts to suit their political objectives. In doing so, they do not engage meaningfully with the legal significance or consequences that should flow from their application of these concepts, an omission that further evidences that their primary concern with invoking human rights language is not to ensure legal remedies for victims of human rights violations, but to harness law's power in their political mobilisation and negotiating strategies.

\subsection{Selectivity in the invocation of human rights law}

A second theme that emerges from the recent submissions of Unionist political parties and aligned organisations are assertions that human rights standards are being applied by existing mechanisms to deal with the past in a narrow and selective manner that disadvantages members of their community. Their submissions reflect concerns that the proposed mechanisms will replicate the approaches they view as problematic. However, as with their invocations of human rights concepts in the previous section, Unionist efforts to highlight gaps and inconsistencies in approaches to the past do not correspond to a concern to ensure that the State's obligations under international

116. 'Assembly Motion Calls for Irish Government Apology', BBC News (18 September 2012) <https://www.bbc.co.uk/news/uk-northern-ireland-19631027> accessed 15 March 2019.

117. Lewis and McDaid (n 112) 635.

118. 'Proposed Agreement: An Agreement Among the Parties of the Northern Ireland Executive on Parades, Select Commemorations, and Related Protests; Flags and Emblems; and Contending with the Past' (31 December 2013) 33 <https://cain.ulster.ac.uk/events/peace/ haass-talks/haass_2013-12-31.pdf> accessed 15 March 2019.

119. Ulster Unionist Party (n 30). 
human rights law are fully implemented, but, rather, can be seen as part of their strategy to uphold their preferred narratives of the past and resist the disclosure of information that enhances their opponents' rival narratives.

A recurring critique of existing and proposed institutions made in Unionist submissions is that they focus too narrowly on deaths. For example, the UUP submission to the NIAC Inquiry complained that institutions proposed in the NIO Consultation 'ignor[e] serious crimes - up to and including attempted murder'. ${ }^{120}$ They contended that, due to this omission, 'thousands of victims of terrorist violence [will] demand that their cases be properly investigated and their human rights be recognised'. ${ }^{121}$ Thus, they acknowledge that the failure to properly investigate these crimes would violate the UK's obligations under international human rights law. The DUP's submission to the NIO Consultation also called for investigations for those who have been seriously injured, but did not link this explicitly to human rights law.

In bringing to light gaps in the proposed mechanisms, the position of the Unionist groups partially overlaps with submissions made by human rights actors. For example, the Northern Ireland Human Rights Commission critiqued the narrow focus on deaths by arguing that Article 2 of the ECHR requires the United Kingdom to investigate 'attempted murders' and Article 3 requires it to investigate 'serious injuries' as well as torture and inhuman or degrading treatment. ${ }^{122}$ The Model Bill Team, which includes CAJ and a number of academics including the author, made similar observations. $^{123}$

Thus, human rights actors share common ground with Unionist positions by calling for investigations into Troubles-related crimes that caused serious injury to victims. However, the human rights actors' submissions go beyond this by recognising that human rights law also requires the State to investigate allegations of torture and inhuman treatment. The failure of Unionist submissions to highlight this gap in compliance with the UK's obligations is consistent with their metaconflict strategies. Where allegations of torture and inhuman treatment have arisen, they have mostly entailed allegations against State actors. Although there are allegations that Republican paramilitaries engaged in torture as part of internal disciplinary actions and in response to alleged criminality, the utility for Unionists in pressing for investigations into this aspect of Republican violence have been undermined by revelations that the IRA's head of internal security was a British agent. ${ }^{124}$ Thus, pushing for the UK to comply with

120. Ulster Unionist Party, 'Northern Ireland Affairs Committee Inquiry into Stormont House Agreement Consultation: Ulster Unionist Party Response' (June 2018) <http://data.parliament.uk/ writtenevidence/committeeevidence.svc/evidencedocument/northern-ireland-affairs-committee/ consultation-on-implementation-of-the-stormont-house-agreement/written/85454.html > accessed 8 March 2019.

121. Ibid. See also The Orange Order (n 102).

122. Northern Ireland Human Rights Commission, 'Submission to NIO's Consultation on Addressing the Legacy of Northern Ireland's Past' (August 2018) paras 2.5-2.10 and 4.4 $<$ http://www.nihrc.org/uploads/publications/NIHRC_Submission_to_NIO\%E2\%80\% 99s_Consultation_on_Addressing_the_Legacy_of_Northern_Ireland\%E2\%80\%99s_Past.pdf> accessed 8 March 2019.

123. Model Bill Team, 'Addressing the Legacy of Northern Ireland's Past: Response to NIO Consultation Public Consultation' <https://s3-eu-west-1.amazonaws.com/caj.org.uk/2018/08/ 30135633/qub-uu-caj-response-to-nio-consultation-aug-18.pdf> accessed 8 March 2019.

124. Vincent Kearney, 'Stakeknife: Ex-IRA and MI5 Members Could be Prosecuted', BBC News (18 December 2018) <https://www.bbc.co.uk/news/uk-northern-ireland-46598765> accessed 15 March 2019. 
its obligations to investigate torture and inhuman treatment would risk exposing the responsibility of State actors for serious human rights violations, which would undermine Unionist narratives on the past. This linkage between the selective identification of gaps and metaconflict narratives was made explicit by the UUP in its submission to the NIAC Inquiry: 'It is hardly surprising that Sinn Fein and the IRA should want the focus to be on fatalities only in order to minimise the true scale of terrorist crimes' ${ }^{125}$ This demonstrates that they want gaps to be addressed only where they are likely to reveal paramilitary responsibility for crimes and thus reinforce their narratives.

Unionists have also argued that the ECHR is being applied inconsistently by existing mechanisms in a manner that privileges victims of State violence over former security force personnel. Under this line of argument, which has been most prominently developed by the NIRPOA, while the State has endeavoured to fulfil its obligations to investigate violations of the right to life under Article 2 of the ECHR, it has failed to respect the rights of retired police officers to a fair trial, which they say is violated by the investigative procedures of the Police Ombudsman. The have also complained that the right of retired police officers to respect for private and family life has been violated by the publication of reports that make findings on historic police misconduct in which 'individuals who have been neither tried nor convicted are either named or so closely identified by description that their families, friends and neighbours may incorrectly assume wrongdoing on their part'. ${ }^{126}$ NIRPOA characterised these findings as 'biased and groundless', stating that the proceedings 'resemble the actions of the Star Chamber in the 17th century'. ${ }^{127}$

The NIRPOA use these criticisms of the existing Police Ombudsman's investigations to justify their calls that the NIO's draft bill be amended in order to provide more robust protections for the Articles 6 and 8 rights of retired police officers who would be subject to investigations by the Historical Investigations Unit (HIU). The current legacy proposals would allow for this body to issue family or interim reports in which an 'individual who was involved in preventing or investigating an event of which the death forms part' could be named, provided that they were given a right to respond to the allegations in advance of publication and the report fairly reflects their response. ${ }^{128}$ Similar to the UUP's criticism that the NIO has shaped the scope of the proposed legacy mechanisms to benefit Republican paramilitaries, the NIRPOA stated that

[i]n relation to retired police officers the proposals are not fair, equitable or proportionate. In order to appease those who are seeking to rehabilitate themselves after a campaign of obscene, cruel and relentless violence and criminality the proposals appear to be prepared to sacrifice even the basic human rights of many retired officers. ${ }^{129}$

The NIRPOA's submission recommends that the NIO draft bill is amended to preclude the HIU from identifying individuals in these family reports, and would instead require that it take steps to protect their identity. They argue that this would provide greater protection for their rights under Articles 6 and 8. However, these changes would severely restrict the information that could be provided to families. Where these recommendations are read alongside statements in the NIRPOA submission that

125. Ulster Unionist Party (n 30).

126. Northern Ireland Retired Police Officers Association (n 54) 9.

127. Ibid 9.

128. Draft Northern Ireland (Stormont House Agreement) Bill, cl 18. See also Draft Northern Ireland (Stormont House Agreement) Explanatory Notes.

129. Northern Ireland Retired Police Officers Association (n 54). 
investigations into the 'mythological creature' of collusion are intended to 'rewrite history' at their expense and to justify the actions of the retired officers' 'political opponents', ${ }^{130}$ it does not seem a stretch to interpret their actions to restrict the information that can result from these investigations as a means to protect their preferred historical narrative of the heroic and law-abiding role played by the Royal Ulster Constabulary during the Troubles.

This section provides examples where Unionist actors have framed their recommendations for changes to the NIO's draft bill to deal with Northern Ireland's past as necessary to ensure greater consistency and compliance with the ECHR. However, on closer inspection, we can see that these appeals are based on a selective engagement with international human rights standards that is designed to control what can be investigated by the proposed Historical Investigations Unit and what information can be shared with families as a result of those investigations. Thus, the appeals to human rights law here are being instrumentalised to serve these actors' metaconflict strategies.

\subsection{Requiring investigative decisions to be taken on the basis of 'balance'}

Although the rule of law is 'an exceedingly elusive notion' ${ }^{131}$ that has long been subject to scholarly debate over the extent to which it should be understood as creating only procedural requirements for creation and application of legal rules, ${ }^{132}$ or as embodying substantive requirements that laws be just and comply with human rights, ${ }^{133}$ there is nonetheless broad and longstanding consensus that the rule of law requires that laws are transparent and provide legal certainty, and that everyone is equal before the law. In addition, all conceptualisations of the rule of law share an understanding that legal institutions should be 'impartial and independent, not subject to political influence or manipulation'. ${ }^{134}$ As Raz argues, to introduce political calculations into prosecutorial decisions would undermine the rule of law. ${ }^{135}$ It would also undermine the perceived or actual independence and impartiality of their work and challenge the legitimacy of their office. However, despite Unionist narratives of the past and their own self-identity emphasising adherence to the rule of law, all submissions by Unionist parties and organisations to the NIO Consultation and parliamentary inquiries called for future decisions on whether to investigate or prosecute legacy offences to be taken on the basis of ensuring that the time, resourcing and outcomes of legacy mechanisms reflect what they understand to be the 'balance' of responsibility for Troubles-related violence, rather than following where the evidence leads and recognising the suffering of victims from all communities.

Calls for approaches to the past to be balanced across ethnic and/or political groupings are common to many post-conflict societies where, like Northern Ireland, they form part of the metaconflict. In addition to the problems they pose for the rule of law, calls for balance are generally viewed as deeply problematic from a human

130. Ibid 7.

131. Brian Z Tamanaha, On the Rule of Law: History, Politics, Theory (CUP, Cambridge 2004) 9.

132. See eg Joseph Raz, The Authority of Law: Essays on Law and Morality (OUP, Oxford 1979); Lon L Fuller, The Morality of Law (Yale UP, New Haven/London 1964).

133. See eg Tom Bingham, The Rule of Law (Penguin, London 2011).

134. Thomas Carothers, 'The Rule of Law Revival' (1998) 77 Foreign Affairs 95, 96.

135. Raz (n 132) 218. 
rights perspective. In addition to undermining equality before the law, ${ }^{136}$ incorporating this criterion into strategies of case selection and prioritisation would inevitably mean that decisions are made neither to investigate nor to refer for prosecution some otherwise deserving cases. Such decisions would deny the affected victims their rights to truth and justice on grounds that could be understood as discriminatory on the basis of their membership of a specific social group. ${ }^{137}$

Like most legal systems, the system of the administration of justice in Northern Ireland allows prosecutors to exercise discretion in deciding whether to proceed with a criminal investigation. However, such discretionary decisions should be based on a two-part test: (1) whether there is sufficient evidence; and (2) whether the prosecution would be in the public interest. With respect to the public interest, international standards provide that '[p]rosecutors shall give due attention to the prosecution of crimes committed by public officials, particularly ... abuse of power, grave violations of human rights ... and, where authorised by law or consistent with local practice, the investigation of such offences'. ${ }^{138}$ This language finds some resonance in Northern Ireland's Code for Prosecutors, which states that among the factors that point to there being a public interest in prosecution is "where the suspect was in a position of authority or trust and the offence is an abuse of that position'. ${ }^{139}$ Neither international nor Northern Ireland standards provide for prosecutorial discretion to be exercised on the grounds of achieving a balance in prosecutions between ethnic or political groups. However, they emphasise the need to prosecute wrongdoing by public officials, a focus that is well-established in international human rights law due to the States' 'monopoly, or at least disproportionate control, over the means of coercion', their greater capacity to commit systematic violations in comparison to non-State armed groups, and the importance of ensuring non-repetition of the crimes and enhancing the legitimacy of State institutions in the aftermath of State human rights violations. ${ }^{140}$

Unionist demands that approaches to deal with the past be balanced centre on understandings of proportionate responsibility for Troubles-related violence. Academic and journalistic research has estimated that between 3,523 and 3,636 people were killed as a result of the 30 -year conflict. ${ }^{141}$ The responsibility for conflict-related

136. Eg Universal Declaration of Human Rights (adopted 10 December 1948 UNGA Res 217 A(III) art 7.

137. UN Guidelines on the Role of Prosecutors, Adopted by the Eighth United Nations Congress on the Prevention of Crime and the Treatment of Offenders, Havana, Cuba, 27 August to 7 September 1990; Public Prosecution Service, 'Code for Prosecutors', paras 1.4-1.6 <https://www.ppsni.gov. uk/Branches/PPSNI/PPSNI/Files/Documents/Publications/Prosecution\%20Policy/Code\%20for\% 20Prosecutors\%20(Interactive)\%202016.pdf> accessed 15 March 2019.

138. UN Guidelines on the Role of Prosecutors (n 137) para 9.

139. Public Prosecution Service (n 137) para 4.13(ii).

140. Frédéric Mégret, 'Is the ICC Focusing Too Much on Non-State Actors?' in Margaret M deGuzman and Diane Marie Amann (eds), Arcs of Global Justice: Essays in Honour of William A. Schabas (OUP, New York 2018) 173.

141. Marie-Therese Fay, Mike Morrissey and Marie Smyth, Northern Ireland's Troubles: The Human Costs (Pluto Press, London 1999); Malcolm Sutton, Bear in Mind These Dead: An Index of Deaths from the Conflict in Ireland 1969-1993 (Beyond the Pale, Belfast 1994); David McKittrick, Seamus Kelters, Brian Feeney, Chris Thornton and David McVea, Lost Lives: The Stories of the Men, Women and Children Who Died as a Result of the Northern Ireland Troubles (Mainstream Publishing, Edinburgh 2001); Michael McKeown, Post-Mortem: An Examination of the Patterns of Politically Associated Violence in Northern Ireland During 
deaths is distributed among Republican paramilitaries, Loyalist paramilitaries and British security forces. The Republicans are deemed to be responsible for around 2,000 deaths, Loyalists for 1,000 deaths, and 360 deaths have been directly attributed to the security forces. These figures do not include cases where there are allegations of collusion between the security forces and paramilitary groups. Thus, on these figures, State forces are directly responsible for 10 per cent of conflict-related deaths. For many Unionist organisations, this means that only 10 per cent of investigative efforts related to dealing with the past should be orientated towards State actors.

There are no comprehensive statistics on how many killings were investigated during the Troubles. However, Bell notes that police statistics claim that 955 alleged paramilitaries were charged with conflict-related deaths. In addition, official figures suggest that up to 30,000 people were imprisoned due to the conflict. ${ }^{142}$ With respect to killings by members of the security forces, in the 'vast majority' of cases that were investigated during the Troubles, the Director of Public Prosecutions for Northern Ireland directed no prosecution. ${ }^{143}$ There were 24 prosecutions involving 34 State actors, with eight being convicted, ${ }^{144}$ most of whom were released early following government intervention. ${ }^{145}$

In the years since the Agreement, the package of measures to deal with the past has included four public inquiries into the role of the British Army in the Bloody Sunday massacre, and allegations of collusion in the deaths of Rosemary Nelson, Billy Wright and Robert Hamill, plus the Smithwick Tribunal in Dublin that investigated collusion between Republican paramilitaries and Irish police with respect to the deaths of two RUC officers. Complaints against the police in Northern Ireland have also been investigated by the Police Ombudsman, which has issued reports into the cases relating to the deaths of 13 individuals (relating to 12 cases), ${ }^{146}$ six terrorist attacks, ${ }^{147}$ and the attempted murder of Gerry Adams. Findings of collusion were only made by some

the Years 1969-2001 as Reflected in the Fatality Figures for those Years (CAIN, Derry/ Londonderry 2009) <https://cain.ulster.ac.uk/victims/mckeown/mckeown01.pdf> accessed 18 January 2019; Fionnuala Ní Aoláin, The Politics of Force: Conflict Management of State Violence in Northern Ireland (Blackstaff Press, Belfast 2000).

142. Office of the First Minister and Deputy First Minister (OFMDFM), 'Report of the Review Panel, Employers' Guidance on Recruiting People with Conflict-Related Convictions' (March 2012) 39 <http://www.reviewpanel.org/wp-content/uploads/2018/02/review-panel-report-2012. pdf> accessed 15 March 2019.

143. British Army, 'An Analysis of Military Operations in Northern Ireland' (July 2006) para 431 <http://www.vilaweb.cat/media/attach/vwedts/docs/op_banner_analysis_released.pdf> accessed 18 January 2019.

144. The cases involving members of the armed forces were $R v$ Thain [1985] NI 457, $R v$ Clegg [1995] 1 AC 482 (acquitted on retrial in 1999) and $R v$ Fisher and Wright (1995) unreported. There were further cases relating to members of the Ulster Defence Regiment. Eighteen UDR soldiers were convicted of murder and 11 of manslaughter during the Troubles; see Chris Ryder, The Ulster Defence Regiment: An Instrument of Peace? (Methuen Publishing, London 1991) 150.

145. Bell (n 22) 1095.

146. See the OPONI reports relating to Frank Hughes, Samuel Devenny, Sean Brown, Eoin David Morley, Jean McConville, Stephen Restorick, Raymond McCord Jr, Paul Whitters, Gerard and Rory Cairns, Sergeant Joe Campbell, Arthur Rafferty, John Hemsworth and Constable John Larmour. Reports available on the website of the Police Ombudsman for Northern Ireland <https://www. policeombudsman.org/Investigation-Reports> accessed 15 March 2019.

147. See the OPONI reports relating to Greysteel, Claudy, McGurks Bar, Creggan Estate in Derry/ Londonderry, Omagh, Loughinisland. See: Police Ombudsman for Northern Ireland (n 146). 
of the inquiries and ombudsman's reports. In addition, 52 legacy inquest cases relating to 93 deaths, many of which relate to allegations of State responsibility or complicity in Troubles-related deaths, have been opened, but have been subject to substantial delay. The Historical Enquiries Team completed reviews of 1,625 cases, which related to 2,051 deaths; of these 1,038 were attributed to Republicans, 536 to Loyalists and 32 to the army, while there were nine cases in which responsibility has not yet been attributed. ${ }^{148}$ In addition, in response to critical commentary concerning a perceived imbalance in conflict-related prosecutions in 2017, the Director of Public Prosecutions provided the following statistics on the 17 prosecutorial decisions on legacy-related cases between 2011 and 2017:

- eight cases relate to alleged offences attributed to Republicans, in seven of the cases decisions were taken to prosecute;

- three cases relate to Loyalists and in all three decisions were taken to prosecute;

- three cases relate to soldiers, two of which have resulted in decisions to prosecute and one a decision not to prosecute; and

- three cases relate to police officers, in two of which decisions were taken not to prosecute, while the third case was discontinued. ${ }^{149}$

Cumulatively, particularly when taken together with the criminal justice proceedings conducted during the Troubles, these data indicate that although there have been more mechanisms investigating wrongdoing by State actors, which have been intensive in time and resources, the number of cases processed by past and existing mechanisms has nonetheless focused heavily on paramilitaries. Furthermore, in data supplied to the Defence Committee in 2017, the PSNI described their 'remaining caseload' as including 379 cases against Republicans, 230 cases against Loyalists and 283 against security forces. This suggests that whereas past investigations have not focused disproportionately on State actors, it is likely that State actors may be subject to greater scrutiny in the coming years, although the majority of cases will continue to relate to paramilitary criminality.

Despite the extensive data in the public domain demonstrating that of the total number of conflict-related deaths that have been investigated or which are in the PSNI's remaining caseload, the vast majority relate to paramilitary crimes, Unionist submissions to the NIO Consultation and parliamentary inquiries have consistently argued that existing mechanisms have focused disproportionately on State actors. For example, in its submission to the NIO consultation, the UUP stated: 'There is no question that the current methods of dealing with the past are imbalanced, unfair and piecemeal'. ${ }^{150}$ In part, this may be because Unionist actors are making claims based on alternative and unsubstantiated numbers. For example, in its submission to the NIO Consultation, the TUV claimed:

The system is skewed against security force personnel and innocent victims of terrorism, with 1615 cases closed down unless the death was 'caused' by the security forces, resulting in 900 cases that involved security forces being prioritised, along with Saville cases. ${ }^{151}$

148. Vincent Kearney, 'Troubles Legacy Cases Bias Disputed by Figures', BBC News (2 February 2017) <https://www.bbc.co.uk/news/uk-northern-ireland-38844453> accessed 1 March 2019.

149. 'DPP has Brought More Cases Against Terrorists than the State, Stats Show', Newsletter (30 January 2017) <https://www.newsletter.co.uk/news/crime/dpp-has-brought-more-casesagainst-terrorists-than-the-state-stats-show-1-7798298> accessed 1 March 2019.

150. Ulster Unionist Party (n 30).

151. Traditional Unionist Voice (n 91). 
However, the TUV gave no indication of the source for its data on the 900 cases being prioritised.

Unionist positions that the current processes focus disproportionately on the State have been adopted by the UK government with the result that the British Prime Minister misled parliament when she stated that 'the only people being investigated for these issues that happened in the past are those in our Armed Forces or those who served in law enforcement in Northern Ireland'. ${ }^{152}$ Through the acceptance of this narrative, the government position has been to confirm the need for new approaches to the past to be balanced. For example, on 6 March 2019, the Northern Ireland Secretary of State, Karen Bradley, affirmed the government's commitment to replacing existing dealing with the past mechanisms with a system that is 'fair, balanced and proportionate'. Then, in response to a question from DUP MP Emma Little Pengelly, the Secretary of State asserted that

over $90 \%$ of the killings during the troubles were at the hands of terrorists. Every single one of those was a crime. The under $10 \%$ that were at the hands of the military and police were not crimes; they were people acting under orders and instructions, fulfilling their duties in a dignified and appropriate way. ${ }^{153}$

The absolute denial of the possibility of criminality on the part of State actors in these inaccurate and insensitive remarks triggered widespread criticism, including calls from victims and others that the Secretary of State resign. ${ }^{154}$ At the time of writing, this pressure has seemingly caused the government to diverge from the Unionist position. On 11 March 2019, as part of a public apology for her previous comments, the Secretary of State stated that ' $[\mathrm{w}]$ here there is any evidence of wrongdoing, this should pursued without fear or favour, whoever the perpetrators might be'. ${ }^{155}$ This statement continued by affirming the government's commitment to the rule of law and that this principle undermined the government's approach to dealing with the past.

Even before this recent apparent change in the government's approach, some Unionist groups have placed the responsibility for the imbalance on State 'appeasement' of terrorists, which they describe as 'circumventing' human rights law, 'as deaths caused by the State are deemed of greater significance than those caused by

152. UK Parliament, 'Prime Minister', Hansard Vol 640 (9 May 2018). See also: 'PM Under Fire Over NI Conflict Cases Comments' ITV News (10 May 2018) <https://www.itv.com/news/utv/ 2018-05-10/pm-under-fire-over-ni-conflict-cases-comments/> accessed 1 March 2019; John Manley, 'PSNI Chief Constable George Hamilton: Theresa May is Wrong About Legacy Cases' Irish News (15 May 2018) <http://www.irishnews.com/news/northernirelandnews/2018/ 05/15/news/george-hamilton-psni-chief-constable-says-theresa-may-is-wrong-about-legacy-cases1329992/> accessed 1 March 2019.

153. Northern Ireland, Oral Answers to Questions, Stormont House Agreement: Legacy, Hansard Vol 655 (6 March 2019) <https://hansard.parliament.uk/commons/2019-03-06/ debates/63BF8914-DC20-419C-A2F0-D91521845987/StormontHouseAgreementLegacy> accessed 12 March 2019.

154. 'Karen Bradley Faces Calls to Resign Over Troubles Comments', BBC News (6 March 2019) <https://www.bbc.co.uk/news/uk-northern-ireland-47471469> accessed 12 March 2019. 155. Point of Order, Hansard Vol 656 (11 March 2019) <https://hansard.parliament.uk/ Commons/2019-03-11/debates/A2BD60A1-53F9-454E-AAA3-7D973F6BC454/

PointOfOrder\#contribution-5CDD395C-CAE2-46DD-ABFC-3659ED73C686> accessed 12 March 2019. 
the terrorists'. ${ }^{156}$ Others argue that the perceived imbalance has arisen as 'human rights obligations mean that some unresolved deaths are more likely to be investigated than others' ${ }^{157}$ In addition, Unionists seek to amplify perceptions of disproportionate focus on State actors by claiming that terrorists have received preferential treatment during the peace process. For example, notwithstanding the eligibility of State actors to benefit from the early release scheme, ${ }^{158}$ the DUP's submission to the NIO Consultation stated:

The failure of the Belfast Agreement to adequately address the needs of innocent victims, whilst facilitating the early release of the terrorist prisoners caused immense hurt to victims. This was further compounded by Government formally abandoning attempting to extradite IRA prison escapees, efforts to grant a terrorist amnesty at Westminster and then comfort letters for those on the run. Twenty years later the Government is still trying to put in place structures to address this unjust imbalance. ${ }^{159}$

Similar statements were made by the UUP in their submission to the NIAC Inquiry. ${ }^{160}$ Through repeatedly emphasising that existing processes are unfair and biased against State actors, Unionist political parties and organisations are expressing their dissatisfaction with the work of past and existing mechanisms that have investigated crimes and abuses committed by State actors. This backdrop informs their attitudes towards the mechanisms proposed in the NIO Consultation.

In the negotiations leading to the Stormont House Agreement 2014 and subsequently to implement that Agreement, Unionists have maintained a constant position that the new processes must be 'balanced, proportionate, transparent, fair and equitable', a position that is reflected in the general principles underpinning the Agreement and in the NIO's draft Bill to give effect to the Agreement. ${ }^{161}$ However, Unionist submissions to the NIO consultation and parliamentary inquiries reveal high levels of scepticism that the proposed mechanisms will deliver the balanced approach for which they are calling. ${ }^{162}$ While some Unionist submissions accept that it may be necessary to investigate some criminality by State actors, all Unionist submissions reflect a resistance to allowing the criminal investigators and prosecutors to go

156. South East Fermanagh Foundation, 'Response to the Northern Ireland Office Consultation Paper' <https://seff.org.uk/wp-content/uploads/2018/10/SEFF-Consultation-Response.pdf > accessed 8 March 2019.

157. Northern Ireland Office, 'Consultation Paper: Addressing the Legacy of Northern Ireland's Past' (May 2018) para 4.5(4) <https://assets.publishing.service.gov.uk/government/ uploads/system/uploads/attachment_data/file/709091/Consultation_Paper_Addressing_the_ Legacy_of_Northern_Irelands_Past.pdf> accessed 14 March 2019.

158. Daniel Holder, "Who Says the Two Year Limit on Prison Sentences for Troubles Offences Excludes the Security Forces?" - Asks CAJ's Daniel Holder', EamonnMallie.com (9 March 2017) <http://eamonnmallie.com/2017/03/who-says-the-two-year-limit-on-prison-sentences-fortroubles-offences-excludes-the-security-forces-asks-cajs-daniel-holder/> accessed 5 March 2019.

159. Democratic Unionist Party (n 100).

160. Ulster Unionist Party (n 120).

161. Stormont House Agreement 2014, para $21<$ https://assets.publishing.service.gov.uk/ government/uploads/system/uploads/attachment_data/file/706293/Stormont_House_Agreement. pdf> accessed 14 March 2019.

162. Traditional Unionist Voice, 'Analysis by TUV of Draft Northern Ireland (Stormont House Agreement) Bill' (July 2018) <http://tuv.org.uk/wp-content/uploads/2018/06/Analysis_by_TUV_ of_Draft_Northern_Ireland.pdf> accessed 8 February 2019. 
where the evidence leads. Instead, they advocate that cases should be reviewed, and if necessary investigated, in relation to proportionate responsibility between the State and paramilitary groups. For example, the DUP stated: 'It is important that any new structures would be proportionate given $90 \%$ of deaths were caused by terrorists, and there should be an end to witch hunts against those in the forces of law and order who acted bravely, honourably and appropriately'. ${ }^{163}$ In a later section, the DUP submission stated: 'The work of the HIU must be proportionate and reflect the fact that over $90 \%$ of murders in Northern Ireland were carried out by terrorists. There must be no more hierarchy of victims, with preferential treatment given to those killed, often legitimately, by the Armed Forces or Police'. ${ }^{164}$ This language indicates that the DUP would accept investigations and prosecutions for unlawful killings by State actors. In addition, the language in the DUP submission could be interpreted to suggest that calculations of proportionality should be forward-looking, and based on an assessment of the caseload of the new institutions. In contrast, the Police Federation for Northern Ireland takes the view that there is a 'deep deficit' in terms of investigations and that calculations of balance should take this into account:

The PFNI are strongly of the view that the future 'legacy landscape' must make-up the current imbalance in legacy investigations between those relating to the state and those attributable to terrorist groups. This should be based upon the metrics of money, working hours and prosecutions across the entire legacy landscape. When such a parity is reached, investigations should proceed on a 1:9 security forces / terrorist ratio for deaths. ${ }^{165}$

This position would require reviews and investigations of cases in which it is alleged that only paramilitary actors are responsible to be prioritised over those for which the State is believed to be responsible. In practice, this would mean either that investigations in which State actors are believed to be directly responsible or complicit in criminality would be postponed indefinitely or may never be opened. This strategy here reflects Lawther's view that 'there is a profound desire among many unionists to use a truth process to place all responsibility for the conflict with paramilitary organisations'. ${ }^{166}$

This section has illustrated that Unionist parties and organisations are seeking to ensure that decisions to investigate and prosecute Troubles-related cases result in what they understand to be a proportionate approach to the past that is reflective of the fact that paramilitaries are directly responsible for 90 per cent of conflict-related deaths. This would represent a significant divergence from existing Northern Irish and international standards that safeguard equality before the law, independence and impartiality in the administration of justice, and non-discrimination. Under their line of reasoning, human rights law has contributed to what they perceive as the disproportionate focus on State actors and in doing so has privileged the rights of victims of State actors over those that Unionists perceive as 'innocent victims'. This argument once again shows an ambivalent and instrumental approach to human rights law, with human rights law being cast as both a problem to be overcome as well as a deficit

163. Democratic Unionist Party (n 100) 2.

164. Ibid.

165. Police Federation of Northern Ireland, 'Submission to the Northern Ireland Office by the Police Federation of Northern Ireland on "Addressing the Legacy of Northern Ireland's Past"" (September 2018) para 2.14 <https://www.policefed-ni.org.uk/media/1321/pfni-response-tolegacy-consultation.pdf> accessed 8 March 2019.

166. Lawther (n 31) 42. 
to be fulfilled. However, depending on how determinations of balance would be calculated within these institutions, they could at least leave open the possibility that wrongdoing by State actors could be investigated. In this respect, they contrast with the fourth theme emerging from the Unionist engagement with dealing with the past, which seeks to prevent any investigations of actions by State forces.

\subsection{Rejecting the application of human rights law to State violations}

Law has long played a significant role in Unionist self-identity. One way in which Unionists distinguish themselves from Loyalists and Republicans is to portray those groups as law-breakers, whereas in contrast, they see themselves as law-abiding citizens. Whereas armed force used by Loyalists and Republicans is portrayed as illegitimate and illegal, Unionists emphasise that the actions of the British Army and the Royal Ulster Constabulary during the Troubles were overwhelmingly lawful acts intended to uphold the rule of law. Their preference for the law has also traditionally been 'evidenced by their unswerving belief in the judicial process and their continued emphasis on the relationship between victims' needs, dealing with the past and criminal prosecutions, regardless of the practicalities of this argument'. ${ }^{167}$ However, as with the themes explored above, this commitment to criminal prosecutions is mitigated by metaconflict strategies in which they emphasise the importance of prosecuting paramilitaries and retaining the possibility of justice for 'innocent' victims, but are more reluctant to see State actors put on trial. Thus, Unionist relationships to criminal prosecutions emerge as part of a strategy to apportion innocence and guilt in individual cases, the collective markers of right and wrong are re-emphasised and the meaning of power, authority and legitimacy re-inscribed'. ${ }^{168}$ Assertions of these aspects of Unionist attitudes to law can be found through the 2018 submissions of the DUP and UUP, but what also emerges are distinct strategies to resist the application of human rights law to the actions of State actors during the Troubles through reinterpreting Article 2's investigative obligations to exclude the actions of State actors or through introducing a statute of limitations. These strategies were prompted by the 2015 decision of the Director of Public Prosecutions to prosecute a British soldier for a conflict-related killing. ${ }^{169}$ This was the first time during the peace process that a British soldier had been charged with a conflict-related offence, and in the subsequent years, the DPP has decided to prosecute three other retired soldiers in two separate cases, ${ }^{170}$ whilst also declining to prosecute others.

167. Ibid 43.

168. Ibid 44.

169. Public Prosecution Service, News Release, 'PPS Confirms Prosecution Against a Former Soldier to Proceed' (10 November 2015) <https://www.ppsni.gov.uk/Branches/PPSNI/PPSNI/ Files/Documents/PPS\%20Press\%20Office/PPS\%20Press\%20Release\%2010\%20November\% 202015.pdf $>$ accessed 23 January 2019.

170. Public Prosecution Service, News Release, 'PPS Confirms Prosecution Decision Against Two Former Soldiers' (16 December 2016) <https://www.ppsni.gov.uk/Branches/PPSNI/ PPSNI/Files/Documents/PPS\%20Press\%20release\%2016\%20Dec\%2016.pdf> accessed 23 January 2019; Public Prosecution Service, News Release, 'PPS Confirms Decision to Prosecute Former Soldier Over 1988 Death' (19 June 2018) <https://www.ppsni.gov.uk/ Branches/PPSNI/PPSNI/Files/Documents/PPS\%20Press\%20Office/PPS\%20press\%20release\% 2019\%20June\%202018\%20v2.pdf> accessed 23 January 2019. 
The first strategy of arguing for a reinterpretation of Article 2 has been articulated by the UUP. The UUP accepts that under Article 2 of the ECHR the UK has obligations to investigate right-to-life violations, but it expresses a 'good deal of frustration' with how Article 2 has been interpreted. The party's submission to the Defence Committee argued that it is inappropriate to apply Article 2 'without any context, to only those killings that involved state forces while ignoring the right to life of members of the military and police service butchered by Republican terrorists'. ${ }^{171}$ Two main recommendations emerge from the UUP's invocation of context. Firstly, the UUP observed that ' $[\mathrm{t}]$ he Government has the ability to argue that the context of the Troubles could realistically prevent Article 2 investigations at the time and any further investigation would not be able to give sufficient detail to ensure a reliable investigation and any charges that may follow'. ${ }^{172}$ The UUP made this observation that the UK government should resist attempting Article 2 investigations as they would not be possible today, even though the NIO's draft bill requires that family reports produced by the Historical Investigations Unit take account of the context in which previous investigations into deaths took place, which can be informed by any persons who are named in those reports as having been part of the initial investigation. ${ }^{173}$

Secondly, the UUP used the context of the Troubles to assert that even where State actors violated human rights, these acts should be understood as isolated and justifiable given its interpretation of the State's objectives as being for the greater good. For example, it proclaimed in its submission to the Defence Committee:

No other European or Western country would believe the type of situation tolerated within the UK by our own legal system, whereby the State and its lawful forces are placed in the dock and made to account for the deaths of terrorists - often already guilty of multiple murders - who were shot dead by the Police or Army as they sought to commit murder, with loaded guns in their hands.

Western Europe today faces a terrorist threat from violent Islamists. The French and Belgian Police have responded with lethal force on a number of occasions. There is quite rightly - no prospect of those Police officers responsible appearing in a dock any time soon, but sadly the same cannot be said of their UK counterparts.

Through this line of argument, the UUP appears to be suggesting that an exception to the State's duty to investigate should be created for security force personnel engaged in anti-terrorism work. Given that right to life is a non-derogable right and the ECHR has established detailed case law on the use of lethal force by State actors, it is unlikely that Strasbourg would be receptive to this argument.

The second strategy under this theme relates to calls for a statute of limitations for UK service personnel, proposals which human rights scholars and practitioners argue may in practice amount to an amnesty for UK armed forces personnel. ${ }^{174}$ The calls for a statute of limitations emerged in the House of Commons Defence Committee report

171. Ulster Unionist Party, 'Written evidence Submitted by Ulster Unionist Party' (n 90).

172. Ibid.

173. Draft Northern Ireland (Stormont House Agreement) Bill, cls 17 and 18.

174. See eg Northern Ireland Human Rights Commission, 'Advice of the Northern Ireland Human Rights Commission on the House of Commons Defence Committee Report on "Investigations in Fatalities in Northern Ireland Involving British Military Personnel"" (June 2017) <http://www.nihrc.org/uploads/publications/NIHRC_Advice_to_NIO_June_2017_Final. pdf> accessed 12 March 2019; House of Commons Defence Committee, 'Written Evidence Submitted by Professor Kieran McEvoy' (7 March 2017) <http://data.parliament.uk/ 
on its inquiry into 'Investigations into Fatalities in Northern Ireland Involving British Military Personnel'. In the report, the Committee (including the DUP MP and former barrister Gavin Robinson) called for a statute of limitations for all Troubles-related incidents 'to protect former service personnel facing investigations into historical allegations'. ${ }^{175}$ The Committee pointed to their perception that the current legacy institutions had a disproportionate focus on former service personnel in PSNI investigations to justify this recommendation. This was followed, in November 2017, by a private members' bill supported by a cross-party group of MPs, including former barrister Emma Little Pengelly and Jim Shannon of the DUP, which called for a ten-year statute of limitations for all UK armed forces personnel, which would apply to all theatres of conflict, including legacy offences related to Northern Ireland and allegations of war crimes that are currently under preliminary examination at the International Criminal Court. The UK government responded to these interventions by agreeing to include a question on the statute of limitation in the public consultation on the NIO draft bill. When the UK ultimately reneged on this commitment, the decision was criticised by the Defence Committee. In response, the Secretary of State wrote to the Committee, setting out political objections to a statute of limitations as well as stating that a statute of limitations only for members of the armed forces could face "considerable legal difficulties' including being 'inconsistent with the UK's obligations under the European Convention on Human Right (ECHR) and with other international obligations'. ${ }^{176}$

Although DUP MPs led the calls for the introduction of a statute of limitations, the party as a whole has been equivocal about these proposals. As a result, the DUP's submission to the NIO only briefly addresses the issue. It noted that the Defence Committee's report had referred to a parliamentary statement in which Jeffrey Donaldson MP argued that a statute of limitations 'would only apply to soldiers and police officers who have previously been the subject of full police investigations'. However, the DUP acknowledged that that this condition is omitted from the Committee's recommendations and it did not assert that Donaldson's requirement that a statute of limitations could only apply postinvestigation would be a condition for the DUP's support. Instead, the submission stated that 'the DUP is supportive in principle of exploring ... legal protections for the armed forces [on a UK-wide basis and covering multiple theatres of conflict], whilst being clear that we would not countenance any amnesty'. ${ }^{177}$ The DUP do not specify how an amnesty would differ from a statute of limitations, but elsewhere in the submission they link amnesty to the rewriting of history and so it is inferred that the party reserves amnesty terminology for measures that would limit criminal liability for paramilitary offences. The UUP position is similar as it expresses its opposition to any statute of limitations proposals that would result in a 'de facto amnesty for terrorists', which they

writtenevidence/committeeevidence.svc/evidencedocument/defence-committee/investigationsinto-fatalities-in-northern-ireland-involving-british-military-personnel/written/48436.html> accessed 12 March 2019.

175. House of Commons Defence Committee, 'Investigations into Fatalities in Northern Ireland Involving British Military Personnel' (24 April 2017) <https://publications.parliament.uk/pa/ cm201617/cmselect/cmdfence/1064/1064.pdf> accessed 23 January 2019.

176. In making these observations, the Secretary of State referred to written and oral evidence provided to the Defence Committee by written and oral testimony by Professor Kieran McEvoy as well as other legal academics. See Northern Ireland Office, Letter to the Defence Committee Chairperson (4 July 2018) <https://www.parliament.uk/documents/SofS_for_Northern_Ireland_to_Chairman_ Legacy_Consultation.pdf> accessed 14 March 2019.

177. Democratic Unionist Party (n 100) 15. 
argue would create 'a danger of equivalence' in which paramilitary violence would be seen as equivalent to violent acts carried out by the State. ${ }^{178}$ However, the UUP indicated that it would support a statute of limitations if a way was found 'to implement a mechanism which they are confident could withstand legal scrutiny and only apply to security force members (former or current) and not be used for terrorists - or indeed stop cases being brought before the ICC if a Statute is implemented'. ${ }^{179}$ Thus, it seems that both the DUP and UUP could be willing to support measures that would prevent prosecutions for former service personnel for Troubles-related offences, but would be reluctant to extend the same measures to paramilitary offences.

\section{CONCLUSION}

International human rights law is intended to provide a universal legal framework that transcends national political debates. With respect to Troubles-related deaths, cases taken by Northern Irish victims' groups and human rights actors to the European Court of Human Rights have set out the obligations on the United Kingdom to investigate violations of the right to life and have provided a mechanism for regularly monitoring the UK's compliance with these obligations. This regional human rights court is independent from the Northern Irish context and it exercises jurisdiction over the UK on the basis of State consent. As such, it could be expected that the relevant international legal standards and the local mechanisms adopted to implement them would be viewed by political actors in Northern Ireland as legitimate and neutral. However, the experience in Northern Ireland, in common with other post-conflict societies, suggests that such optimism may be 'problematic'. ${ }^{180}$

This article has demonstrated that, instead, where Unionist political parties and aligned organisations have engaged with international human rights obligations to investigate past violations, they have done so from a position of scepticism and resistance. Their submissions to the NIO consultation and parliamentary inquiries on dealing with the past during 2018 illustrate how Unionist actors view existing mechanisms to fulfil these human rights obligations as unfair and contrary to their objectives. On this basis, these groups call for reforms to reinterpret human rights norms and obligations in ways that limit accountability for State actors and privilege investigatory efforts that are designed to lay responsibility for Troubles-related offences with paramilitaries. For these Unionist actors, law is not separate from politics. Law's power is understood as providing a means to construct and provide official recognition for communally resonant moral and social categories and norms. Thus, legal principles such as the equality of the law, non-discrimination, and independence within the criminal justice process are viewed as secondary to political concerns. These actors adapt or sideline these principles to fit their preferred political outcomes. In doing so, Unionists articulate exclusionary narratives that stand in tension with the inclusivity that is promised by human rights law. ${ }^{181}$ Unionists are not alone in waging these metaconflicts in

178. Ulster Unionist Party (n 120).

179. Ulster Unionist Party, 'Written Evidence Submitted by Ulster Unionist Party' (n 90).

180. Bronwyn Anne Leebaw, 'The Irreconcilable Goals of Transitional Justice' (2008) 30 Human Rights Quarterly 95, 103.

181. Jonathon Goldberg-Hiller, The Limits to Union: Same-Sex Marriage and the Politics of Civil Rights (University of Michigan Press, Ann Arbor 2002); see also Joel Bakan, Just Words: Constitutional Rights and Social Wrongs (University of Toronto Press, Toronto 1997). 
contemporary Northern Ireland, and their positions on human rights law should be understood within a context in which multiple parties seek to propagate their preferred narratives of the past in order to further their ongoing struggle over the constitutional status of Northern Ireland. Although many elements of Northern Ireland's metaconflict are highly context-specific, ${ }^{182}$ its experiences of the battles waged over the identification of past harms to be addressed, the responses to those harms that are advocated, the attributions of responsibility, and the politicised evaluations of dealing with the past processes or proposals have resonances in other post-conflict societies.

Since the 1998 peace agreement, Northern Ireland has achieved remarkable success in the endurance of its peace process and the immense reduction of political violence. However, arguably the persistence of its metaconflict 20 years into the peace process, when viewed together with the collapse of the devolved institutions, shows how Northern Ireland's progress towards reconciliation and stable democratic institutions has stalled, ${ }^{183}$ with the result that its peace process remains fragile and at risk from the potential fallout of Brexit. In addition, although all the main political actors agree that Northern Ireland's current mechanisms for dealing with the past are failing to deliver for victims, the unwillingness or inability of significant political actors to look beyond their entrenched metaconflict positions means that Northern Ireland has been trapped for over a decade in multiple rounds of consultations and negotiations on how to develop a comprehensive approach to deal with the past, while victims and their families continue to wait for their cases to be investigated. Arguably, this political fragility can be attributed to the destructive effects of the absence of a metabargain.

When metaconflict protagonists remain intent on achieving victory, in terms of control over the hegemonic narrative that would be imposed on adversaries, they are rarely able to reach a metabargain. ${ }^{184}$ To reach such a pact, the parties must recognise that the status quo is destructive, they must decide that it will be impossible for them to win the victory they seek and that it would be preferable to pursue a mutually beneficial settlement, and they must be willing to compromise on some aspects of their own position and be receptive to hearing the positions of others. ${ }^{185}$ Where parties can agree to create mechanisms tasked with raising awareness of multiple and complex conflict narratives, these processes can support metabargain understandings of the past in which all sides recognise the harms experienced by others. Such approaches do not mean that there should be 'a single version and interpretation of the past shared by a whole society whatever its scope and size'. ${ }^{186}$ Instead, as the experience of the South African Truth and Reconciliation Commission indicates, what is often sought is official acknowledgement of individual experiences together with a 'social truth' which is 'the truth of experience that is established through interaction, discussion and debate'. ${ }^{187}$ For the Commission, this dialogic process should seek to 'transcend the divisions of the past by listening carefully to the complex motives and perspectives

182. Grech (n 77) 222.

183. 'Proposed Agreement' (n 118) 1.

184. Pierre du Toit and Jannie Gagiano, 'Contending Regime Models and the Contest for the Middle Ground in South African Politics' (1988) 15 Politikon 5, 7.

185. McGarry (n 2) 80-81.

186. Elizabeth Jelin, 'Public Memorialization in Perspective: Truth, Justice and Memory of Past Repression in the Southern Cone of South America' (2007) 1 International Journal of Transitional Justice 138, 140.

187. South African Truth and Reconciliation Report, Vol 1, 113 (citing Albie Sachs, 'The Task for Civil Society' in Alex Boraine and Janet Levy (eds), The Healing of a Nation (Justice in Transition, Cape Town 1995) 103, 105). 
of all those involved'. The Commission argued that this listening process could affirm the dignity of human beings and the essential norms of social relations between people. As Ricoeur contends, 'having confidence in the word of others' reinforces the interdependence and 'shared common humanity' of all members of society. ${ }^{188}$

The process of adopting and moving towards implementing the Stormont House Agreement demonstrates that the Northern Irish political parties, together with the UK and Irish governments, have come a considerable distance towards reaching a metabargain. There seems to be a broad consensus that the status quo is not working and that new approaches need to be created. The NIO's draft bill proposes a number of processes that would allow multiple experiences of the Troubles to be testified to, investigated, listened to, and acknowledged. Furthermore, it would create an Implementation and Reconciliation Group, which would be tasked with encouraging initiatives to contribute to reconciliation and reducing sectarianism, and commissioning academic research to explore 'themes and patterns' relating to individuals' experiences of the Troubles. However, this article demonstrates that rather than embracing the possibilities offered by these processes, Unionist submissions to the NIO consultation and public inquiries demonstrate a commitment to seek to shape these mechanisms to ensure that the information that results bolsters Unionist positions in the metaconflict. For these proposals to deliver meaningfully for victims and Northern Irish society, Unionists and other political groups need to eschew zero-sum approaches and to recognise the need for political generosity and compromise, in which all parts of the society are able 'to take ownership of and acknowledge their role in the past'. ${ }^{189}$ A more substantive engagement with the principles of universality and equality underpinning international human rights could provide a framework to deal with the past in a fair and dignified manner for all. ${ }^{190}$

188. Paul Ricoeur, Memory, History, Forgetting (University of Chicago Press, Chicago and London 2004) 166.

189. Lawther (n 31) 26.

190. Grech (n 77) 221. 